\title{
A novel supported Katsuki-type (salen)Mn complex for asymmetric epoxidation $\uparrow$
}

\author{
Keith Smith,* Chia-Hui Liu and Gamal A. El-Hitił \\ Received 12th December 2005, Accepted 20th January 2006 \\ First published as an Advance Article on the web 1st February 2006 \\ DOI: 10.1039/b517611p
}

We have successfully prepared an unsymmetrical analogue of a Katsuki-type salen ligand having a hydroxyalkyl group at the 6-position of just one of the binaphthyl units in the ligand, and also several Mn(III) complexes; these complexes have been attached to a polymer by an ester link and such polymer catalysts have been shown to be highly enantioselective and recoverable catalysts for the epoxidation of 1,2-dihydronaphthalene.

\section{Introduction}

Enantioselective epoxidation using chiral (salen)Mn(III) complexes has become a useful preparative method in organic synthesis. ${ }^{1,2}$ Several suitable chiral (salen)Mn complexes have been developed, particularly by Jacobsen, ${ }^{1}$ Katsuki, ${ }^{2}$ and co-workers. The chiral (salen)Mn complexes have been found to be effective catalysts for asymmetric epoxidation of alkenes with high levels of enantioselectivity over a wide range of substrates. ${ }^{1,2}$ However, such homogeneous catalysts are not easily recovered for reuse or recycle. By contrast, heterogeneous catalysts offer easy separation from products and facile recovery for recycling.

Recently, there have been many studies of the immobilisation of analogues of Jacobsen-type homogeneous catalysts such as [ $N, N^{\prime}$-bis(3,5-di-tert-butylsalicylidene)-1,2-cyclohexanediamine]$\mathrm{Mn}$ (III) chloride onto solid supports, including organic polymers ${ }^{3-9}$ a polysiloxane, ${ }^{10}$ zeolites, ${ }^{11,12}$ a clay, ${ }^{13}$ silica gel, ${ }^{14}$ MCM-41 ${ }^{15-17}$ and activated carbons. ${ }^{18}$

Thus far, the most effective methods have used organic polymer supports. Unfortunately, such immobilization has often caused significant decreases in the enantioselectivity the catalysts display. ${ }^{5}$ For a successful polymer-supported catalyst that is stable, does not leach, can be recovered and gives high enantioselectivity, the catalytic moiety should be covalently bound to the polymer by a single point of attachment and with a suitable spacer group. We recently gave a preliminary account of the synthesis of such a complex. ${ }^{19}$ We now report the full details of that work.

As our target complex for attachment to a polymer we chose 1, an analogue of the Katsuki complex 2, rather than a Jacobsentype complex, for the following reasons: i) no supported Katsukitype complexes have previously been prepared; ii) Katsuki-type complexes give higher enantioselectivities for epoxidation of certain types of alkenes; ${ }^{2 a}$ iii) Katsuki-type complexes are bulky and less prone to oxidative dimerisation reactions; ${ }^{20}$ iv) the ligand

Centre for Clean Chemistry, Department of Chemistry, University of Wales Swansea, Singleton Park, Swansea, UK SA2 8PP

$\dagger$ Electronic supplementary information (ESI) available: Details of the instrumentation and materials used and experimental details for the previously reported compounds $9, \mathbf{1 0}, \mathbf{1 7}, \mathbf{1 8}, \mathbf{3}, \mathbf{2 3}, \mathbf{2 4}$ and $\mathbf{2 2}$. See DOI: $10.1039 / \mathrm{b} 517611 \mathrm{p}$

$\$$ Permanent address: Department of Chemistry, Faculty of Science, Tanta University, Tanta 31527, Egypt may be more stable to decomposition; v) the hydroxyalkyl group would allow attachment to several different kinds of support, both organic and inorganic.

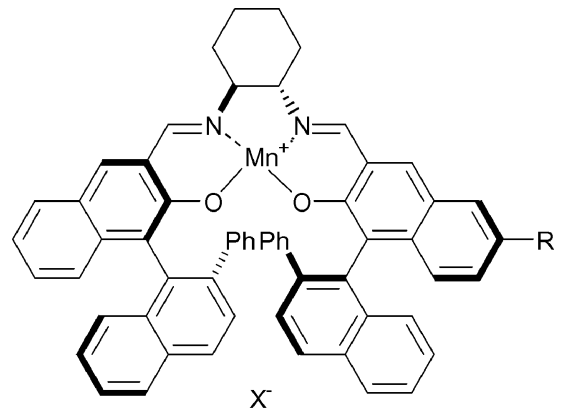

$$
\begin{aligned}
& \text { 1a } \mathrm{R}=\mathrm{CH}_{2} \mathrm{CH}_{2} \mathrm{CH}_{2} \mathrm{OH}, \mathrm{X}=\mathrm{AcO} \\
& \text { 1b } \mathrm{R}=\mathrm{CH}_{2} \mathrm{CH}_{2} \mathrm{CH}_{2} \mathrm{OH}, \mathrm{X}=\mathrm{PF}_{6} \\
& \text { 1c } \mathrm{R}=\mathrm{CH}_{2} \mathrm{CH}_{2} \mathrm{CH}_{2} \mathrm{OH}, \mathrm{X}=\mathrm{CF}_{3} \mathrm{SO}_{3} \\
& \text { 2 } \mathrm{R}=\mathrm{H}, \mathrm{X}=\mathrm{PF}_{6}
\end{aligned}
$$

\section{Results and discussion}

\section{General approach}

The synthetic approach to 1 required the coupling of the known compound $\mathbf{3}$, which we prepared by the literature route, ${ }^{21}$ with $1,2-$ cyclohexanediamine (4), followed by coupling of the intermediate (5) with the novel compound 6 (Scheme 1). The synthetic route to $\mathbf{6}$ is described in Scheme 2.

Synthesis of substituted salicylaldehyde derivative 6. Bromine was introduced after one of the $\mathrm{OH}$ groups of the binaphthol had been replaced by phenyl, when the two naphthalene rings would have very different reactivities, so that formation of a selectively substituted compound was possible. Compound $\mathbf{1 1}$ was easily obtained in an almost quantitative yield from $\mathbf{1 0}$ by this approach.

Conversion of $\mathbf{1 1}$ into $\mathbf{1 2}$ by a Heck reaction, ${ }^{22}$ followed by successive reductions of the double bond and the ester group, was straightforward. Compound 11 was converted into 12 (96\% yield, $90 \%$ purity by ${ }^{1} \mathrm{H}$ NMR) with methyl acrylate in the presence of palladium acetate, tri( $o$-tolyl)phosphine, and anhydrous sodium acetate in $N, N$-dimethylformamide (DMF) at $130^{\circ} \mathrm{C}$. The NMR spectrum showed the presence of a large coupling constant 
<smiles>O=Cc1cc2ccccc2c(-c2c(-c3ccccc3)ccc3ccccc23)c1O</smiles>

3<smiles>NC1CCCCC1N</smiles><smiles>N[C@@H]1CCCCC1N=Cc1cc2ccccc2c(-c2c(-c3ccccc3)ccc3ccccc23)c1O</smiles>

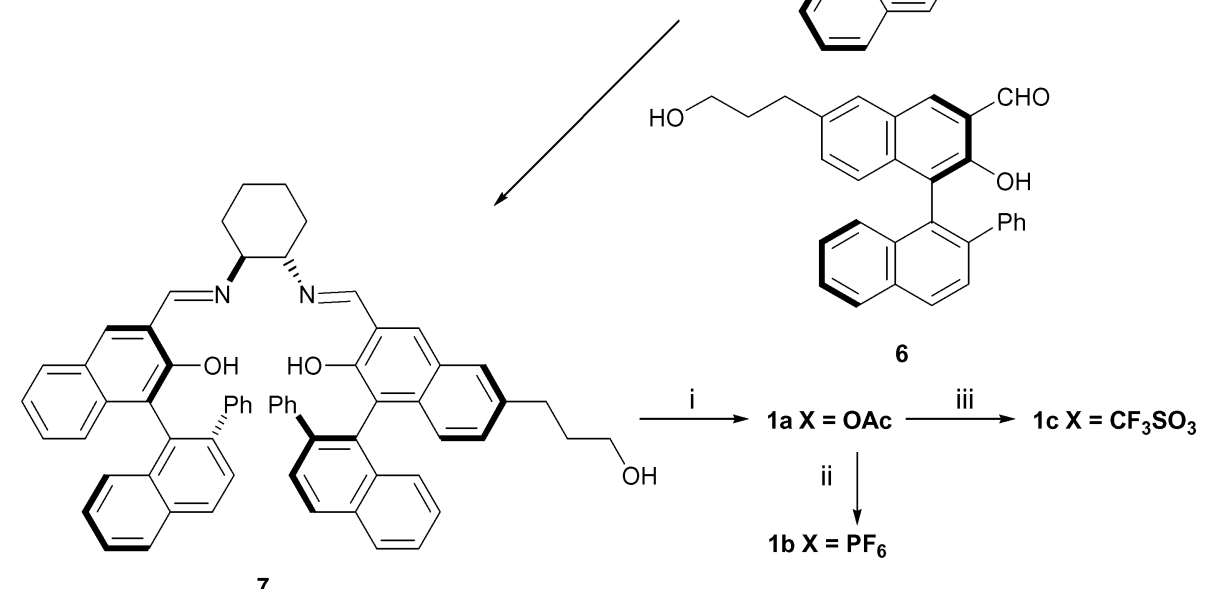

Scheme 1 Reagents: i) $\mathrm{Mn}(\mathrm{OAc})_{2} \cdot 4 \mathrm{H}_{2} \mathrm{O}$, air; ii) $\mathrm{NaPF}_{6}$; iii) $\left(\mathrm{CF}_{3} \mathrm{SO}_{2}\right)_{2} \mathrm{O}$.<smiles>Oc1ccc2ccccc2c1-c1c(O)ccc2ccccc12</smiles>

8<smiles>[R]c1ccc2ccccc2c1-c1c(O)ccc2ccccc12</smiles><smiles>[X]c1cc2ccccc2c(-c2c(-c3ccccc3)ccc3ccccc23)c1[R]</smiles>

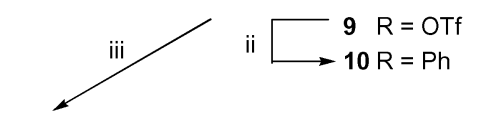

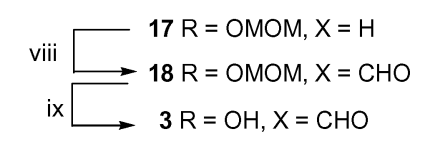<smiles>Oc1ccc2cc(Br)ccc2c1-c1c(-c2ccccc2)ccc2ccccc12</smiles><smiles>[R]c1ccc2c(-c3c(-c4ccccc4)ccc4ccccc34)c(O)ccc2c1</smiles>

11

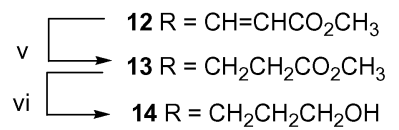<smiles>COCCCc1ccc2c(-c3c(-c4ccccc4)ccc4ccccc34)c(OC)c(C=O)cc2c1</smiles>

16

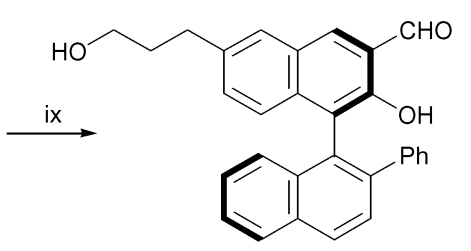

6

Scheme 2 Reagents: i) $\mathrm{Tf}_{2} \mathrm{NPh}, 2,4,6$-collidine, DMAP, $\mathrm{CH}_{2} \mathrm{Cl}_{2}$, reflux, 24 h; ii) $\mathrm{PhMgBr}, \mathrm{NiCl}_{2}(\mathrm{dppe}), \mathrm{Et}_{2} \mathrm{O}$, reflux, 2 h; iii) $\mathrm{Br}$; iv) methyl acrylate, $\mathrm{Pd}(\mathrm{OAc})_{2}, \mathrm{P}(o \text {-tol })_{3}, \mathrm{CH}_{3} \mathrm{COONa}, \mathrm{DMF}, 130{ }^{\circ} \mathrm{C}$; v) $\mathrm{Mg}-\mathrm{CH}_{3} \mathrm{OH}$; vi) $\mathrm{LiAlH}_{4}$-ether; vii) $\mathrm{i}-\mathrm{Pr}_{2} \mathrm{NEt}, \mathrm{CH}_{3} \mathrm{OCH}_{2} \mathrm{Cl}_{,} \mathrm{CH}_{2} \mathrm{Cl}_{2} ;$ viii) $t$ - $\mathrm{BuLi}, \mathrm{THF},-78{ }^{\circ} \mathrm{C}, 3 \mathrm{~h}$, then DMF, $20^{\circ} \mathrm{C}, 1 \mathrm{~h}$; ix) $\mathrm{Me}_{3} \mathrm{SiBr}, \mathrm{CH}_{2} \mathrm{Cl}_{2}$. 
$\left(J_{\text {trans }}=16 \mathrm{~Hz}\right)$ for the vinylic hydrogens indicating that the trans form was present as the major component. The cis form was also present to a small extent $\left(J_{c i s}=12 \mathrm{~Hz}\right)$. There was no need to separate the two isomers as the mixture could be used directly for the subsequent steps. Reduction of 12 using magnesium in methanol ${ }^{23}$ gave $\mathbf{1 3}$ in $61 \%$ yield after purification by column chromatography. Reduction of $\mathbf{1 3}$ using lithium aluminium hydride ${ }^{24}$ gave $\mathbf{1 4}$ in $70 \%$ yield after crystallization from chloroform.

Protection of the two hydroxyl groups of $\mathbf{1 4}$ as MOM ethers was curiously difficult, 15 being obtained in only $60 \%$ yield, along with $40 \%$ of monoprotected (in the side chain) product, even with a large excess of $\mathrm{MOMCl}$, although it was easy to protect the $\mathrm{OH}$ group of $\mathbf{1 0}$ with only a modest excess of reagent. However, compound 15 was purified by column chromatography on alumina and its structure was confirmed by the ${ }^{1} \mathrm{H}$ NMR spectrum, which showed a singlet $\mathrm{CH}_{2}$ signal at $4.62 \mathrm{ppm}$ for the MOM group in the side chain at C-6, and two doublets at $4.73 \mathrm{ppm}$ and $4.87 \mathrm{ppm}$ for the diastereotopic hydrogens of the methylene part of the MOM group at C-2.

Compound 15 was next converted into 16 by ortho-metallationformylation. Treatment of $\mathbf{1 5}$ with tert-butyllithium and then $N, N$-dimethylformamide afforded aldehyde $\mathbf{1 6}$ in $60 \%$ yield and recovered 15 in $40 \%$ yield under the standard conditions used by Katsuki et $a .^{21}$ Removal of the protecting groups with trimethylsilyl bromide gave $6(92 \%)$, after a long reaction time under the standard conditions used by Katsuki et al. ${ }^{21}$

Synthesis of the unsymmetrical salen ligand 7 and its Mn complexes. There are claims in the literature for the high yield synthesis of simple unsymmetrical salen ligands by the sequential addition of two different aldehydes to cyclohexane1,2-diamine. ${ }^{25}$ However, these claims have been challenged. ${ }^{26} \mathrm{We}$ attempted the synthesis of the half-salen ligand 5 by reaction of a 1: 1 mixture of $\mathbf{3}$ and $\mathbf{4}$ in chloroform, according to the literature method, ${ }^{25}$ but the reaction product contained three components, the mono-imine (5), the bis-imine ligand (19a) and the cyclohexanediamine (4), according to ${ }^{1} \mathrm{H}$ NMR, and it proved difficult to obtain pure $\mathbf{5}$ from the mixture. The problem appeared to involve conversion of the mono-imine $\mathbf{5}$ into a mixture of 4 and 19a.

Recent reports have indicated that half-salen ligands can be purified as salts, ${ }^{27}$ but these reports appeared after our experiments.

Bis-imine ligands are known to be more stable than monoimines. ${ }^{26}$ Therefore, in order to avoid losing 5 through equilibration, 3 was reacted with two equivalents of $\mathbf{4}$ and the proportion of 5 : 19a was estimated by the ${ }^{1} \mathrm{H}$ NMR spectrum to be $3: 1$. Compound $\mathbf{6}$ (molar amount equal to that of $\mathbf{5}$ present in the mixture) was added and the mixture was stirred for $3 \mathrm{~h}$ at room temperature. Column chromatography of the product mixture on silica in the presence of excess cyclohexanediamine produced pure samples of the three bis-imines: 19a, 7 and 19b. The yield of 7 was $c a .80 \%$ based on the amount of 6 used, while the yield of 19b was $c a$. 20\%. The symmetrical compounds 19a and $19 \mathrm{~b}$ could be recycled by decomposing them in $4 \% \mathrm{HCl}$ to give back the salicylaldehydes $\mathbf{3}$ and $\mathbf{6}$, respectively.

Salen ligand 7 was successfully converted into its manganese complexes, 1a-c, which were more stable and could be purified by chromatography without any problem.

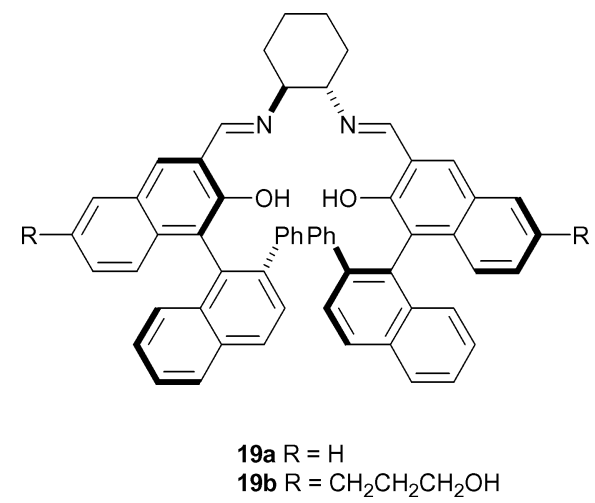

Synthesis of polymer-model derivatives of compounds related to 1. Our initial intention was to attach the chiral salen ligand or its Mn complex via an ether linkage to a polystyrene resin. However, all of our attempts to link a model hydroxyalkyl compound $\mathbf{1 4}$ to benzyl chloride, iodide or triflate resulted in problems that would be difficult to handle with a polymeric substrate. Therefore, we decided to investigate instead the coupling of the ligand and/or complex via an ester link.

Ligand 7 was stirred with benzoyl chloride and triethylamine at room temperature for $24 \mathrm{~h}$, at which time TLC indicated the presence of a new component. Purification of a small aliquot of the product by column chromatography on silica gel in the presence of cyclohexanediamine gave $\mathbf{7}$ and $\mathbf{2 0}$ in a weight ratio of about $2: 1$. The rest of the reaction mixture was heated to reflux for an additional $24 \mathrm{~h}$. After purification by column chromatography, 7 and 20 were then obtained in a weight ratio of $c a .1: 3$, with no detectable decomposition of the ligand.
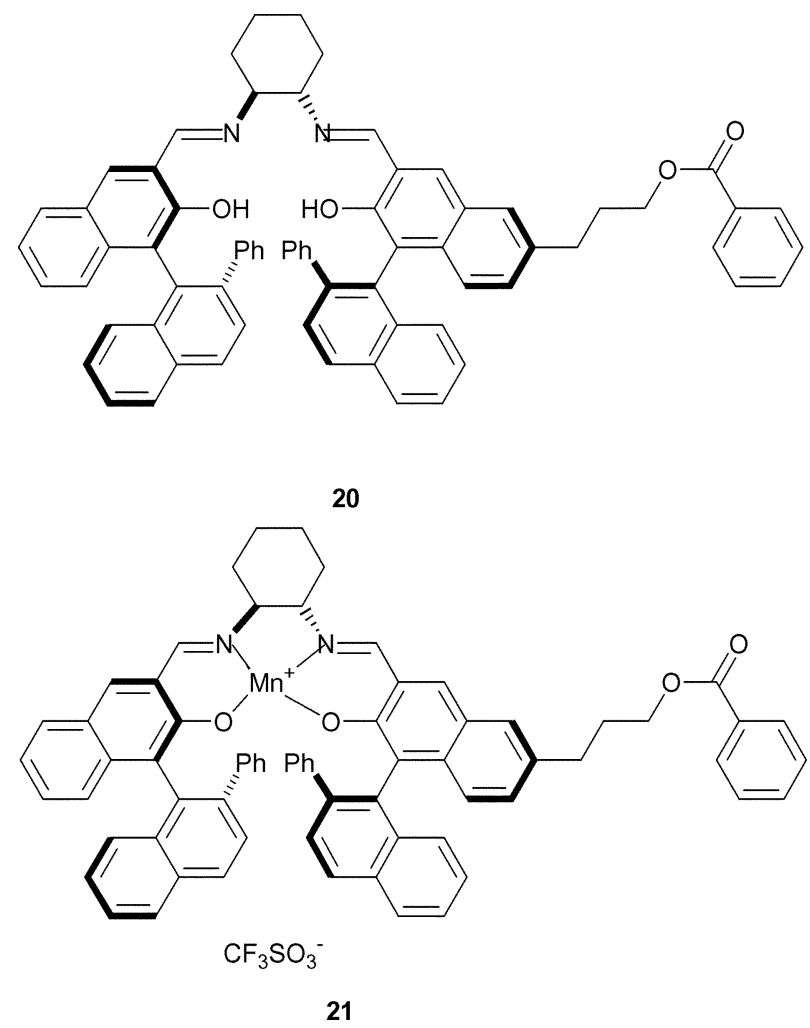

Treatment of complex 1c with benzoyl chloride and triethylamine under reflux for $48 \mathrm{~h}$ gave a $72 \%$ yield of the corresponding 
benzoate 21 and 5\% of recovered 1c. Negative ion electrospray mass spectrometry showed that the benzoate retained a triflate anion. The FT-IR spectrum showed a characteristic imine group at $1602 \mathrm{~cm}^{-1}$ and a new absorption at $1715 \mathrm{~cm}^{-1}$ corresponding to an ester group (see ESI $\dagger$ ). In view of the success with benzoylation of both 7 and 1c, the next step was to synthesise the polystyrenecarbonyl chloride.

Synthesis of polystyrenecarbonyl chloride (22). Synthesis of 22 was achieved from Merrifield's resin (Scheme 3). ${ }^{28-31}$ Formylpolystyrene (23) was prepared by the oxidation of chloromethylated polystyrene using DMSO-NaHCO 3 according to a literature procedure. ${ }^{28}$ The IR spectrum of the polymersupported aldehyde showed that the $-\mathrm{CH}_{2} \mathrm{Cl}$ vibration band at $1266 \mathrm{~cm}^{-1}$ in Merrifield's resin had been replaced by a new strong band at $1699 \mathrm{~cm}^{-1}$, assigned to a carbonyl group. There was also an aldehydic $\mathrm{C}-\mathrm{H}$ absorption around $2720 \mathrm{~cm}^{-1}$.

Carboxypolystyrene (24) was prepared by a Baeyer-Williger type oxidation of $\mathbf{2 3}$ with $m$-chloroperoxybenzoic acid ( $m$-CPBA) in 1,2-dimethoxyethane (DME). ${ }^{29}$ The IR spectrum of $\mathbf{2 4}$ showed an intense absorption at $1701 \mathrm{~cm}^{-1}$ with a shoulder at $1730 \mathrm{~cm}^{-1}$, corresponding to $\mathrm{H}$-bonded and free carbonyl groups. There was also a very broad hydroxyl absorption at $3457 \mathrm{~cm}^{-1}$. Acid-

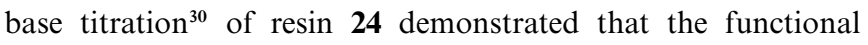
yield of carboxyl groups was around $70 \%$ of that expected from the assumed concentration of chloride groups in the original Merrifield resin.

Leznoff et al. have reported conversion of carboxypolystyrene (24) into its acid chloride by treatment with thionyl chloride in benzene. ${ }^{31}$ Application of this procedure gave a polymer-supported acid chloride. The IR spectrum showed that the $\mathrm{C}=\mathrm{O}$ bands at $1730 \mathrm{~cm}^{-1}$ and $1701 \mathrm{~cm}^{-1}$ in carboxypolystyrene had been replaced by a new broad absorption band at $1700-1780 \mathrm{~cm}^{-1}$,

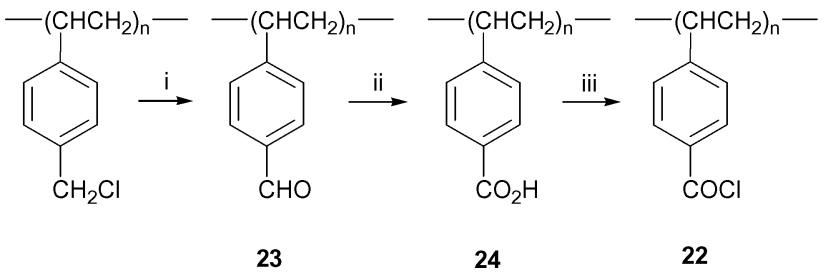

Scheme 3 Reagents: i) DMSO, $\mathrm{NaHCO}_{3}, 155^{\circ} \mathrm{C}, 6 \mathrm{~h}$; ii) $m-\mathrm{ClC}_{6} \mathrm{H}_{4} \mathrm{CO}_{3} \mathrm{H}$, DME, reflux, $24 \mathrm{~h}$; iii) $\mathrm{SOCl}_{2}$, benzene, reflux, $20 \mathrm{~h}$. which was assigned to a-COCl group. Hydrolysis and analysis of the liberated $\mathrm{HCl}\left(\mathrm{ca} .1 .17 \mathrm{mmol} \mathrm{g}^{-1} \mathrm{Cl}\right)$ indicated that $86 \%$ of the carboxyl groups in $\mathbf{2 4}$ had been converted into carbonyl chloride groups in 22.

Attachment of unsymmetrical chiral (salen)Mn(III) complexes 1 to polystyrenecarbonyl chloride (22). The acid chloride resin (22) was treated with various samples of unsymmetrical (salen)Mn complexes 1 as shown in Scheme 4. Polymer A was obtained directly from 1a and had the structure 25a. Polymer $\mathbf{B}$ was obtained from 1c, but the initial polymer triflate salt $25 \mathbf{c}$ was converted into the hexafluorophosphate by treatment with $\mathrm{NaPF}_{6}$. Thus, polymer $\mathbf{B}$ had the structure 25b. Polymer $\mathbf{C}$ was also 25b, but obtained directly from $\mathbf{1 b}$. The polymers obtained were characterised by their infrared spectra. The spectra showed that the broad $-\mathrm{COCl}$ absorption band at $1700-1780 \mathrm{~cm}^{-1}$ in polymer 22 had been replaced by an ester absorption band at $c a .1721 \mathrm{~cm}^{-1}$ in all three polymer samples. Also, the absorption signals at $c a .1602 \mathrm{~cm}^{-1}$ were broader and more intense than that of polymer 22, attributed to the additional presence of the stretching vibration of the $-\mathrm{C}=\mathrm{N}-$ group.

Each resin was estimated by determination of its Mn concentration by atomic absorption spectroscopy (AAS). A sample of the polymer was calcined at $550{ }^{\circ} \mathrm{C}$ to produce an ash, which was treated with a mixture of hydrochloric and nitric acids $(3: 1)$, heated to dryness and then dissolved in distilled water and diluted to an appropriate volume. AAS of the solution was compared with a calibration curve to give the amount of $\mathrm{Mn}$ present. These analyses indicated that the polymers contained around $0.096 \mathrm{mmol} \mathrm{g}^{-1}$ (polymer A, 25a), $0.12 \mathrm{mmol} \mathrm{g}^{-1}$ (polymer B, 25b) and $0.24 \mathrm{mmol} \mathrm{g}^{-1}$ (polymer $\mathbf{C}, \mathbf{2 5 b}$ ), which correspond to about $18 \%, 23 \%$ and $45 \%$, respectively, of the amount expected for $100 \%$ incorporation of the salen complex.

Asymmetric epoxidation using the polymer-supported unsymmetrical chiral (salen)Mn(III) complexes. The catalytic activity and selectivity of the immobilised chiral (salen)Mn complexes were tested in the epoxidation of 1,2-dihydronaphthalene (26) using sodium hypochlorite $(\mathrm{NaOCl})$ as the oxidant and 4-phenylpyridine $N$-oxide (4-PPNO) as the activator (Scheme 5). The conditions for these reactions were analogous to those used by Katsuki et al. for related homogeneous catalysts. ${ }^{32}$ Analogues $\mathbf{2}$ and $\mathbf{1 b}$ were also tested. The results are reported in Table 1.

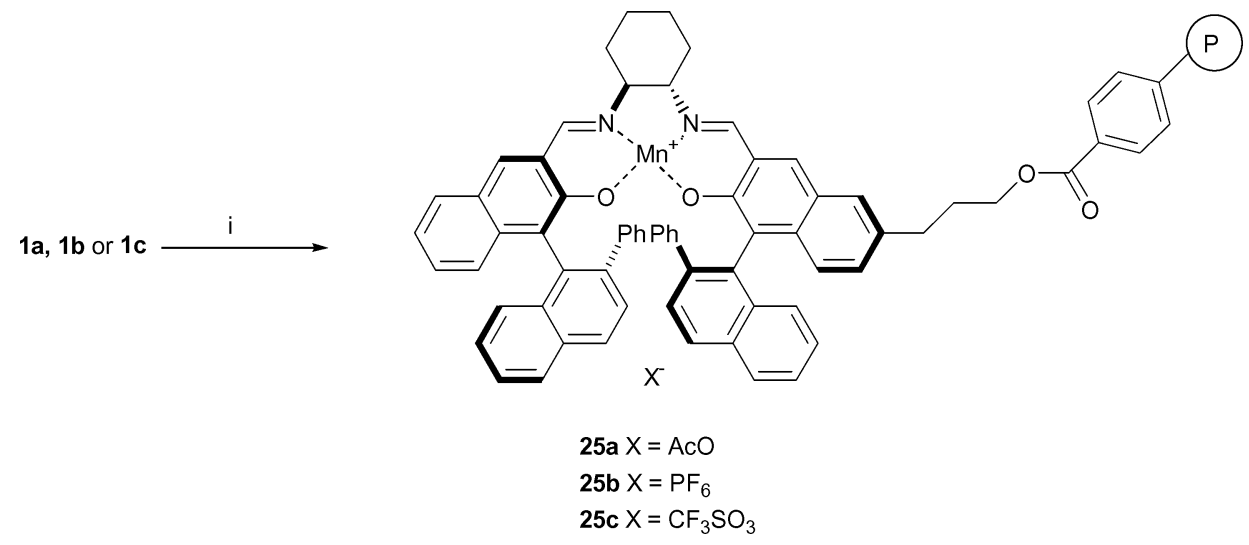

Scheme 4 Reagents: i) polystyrenecarbonyl chloride, excess $\mathrm{Et}_{3} \mathrm{~N}, \mathrm{CH}_{2} \mathrm{Cl}_{2}$, reflux. 
Table 1 Asymmetric epoxidation of 1,2-dihydronaphthalene (26) using (salen)Mn complexes ${ }^{a}$

\begin{tabular}{|c|c|c|c|c|c|c|c|c|}
\hline No & Catalyst & Number of uses & \multicolumn{2}{|c|}{ Catalyst } & Alkene/mmol & Time/h & Yield $(\%)^{b}$ & $\operatorname{Ee}^{c}(\%)$ \\
\hline 1 & 2 & & 10 & 0.04 & 0.2 & 7.5 & 100 & $\geq 94$ \\
\hline 2 & 1b & & 10 & 0.04 & 0.2 & 6.5 & 100 & $\geq 94$ \\
\hline 3 & Polymer A & $1^{\text {st }}$ & 83 & 0.032 & 0.16 & 72 & 68 & - \\
\hline 4 & Polymer A & $2^{\text {nd }}$ & 72 & 0.028 & 0.14 & 72 & 40 & ca. 90 \\
\hline 5 & Polymer B & $1^{\text {st }}$ & 87 & 0.042 & 0.21 & 48 & 40 & ca. 94 \\
\hline 8 & Polymer B & $4^{\text {th }}$ & 17 & 0.008 & 0.04 & 142 & 40 & ca. 93 \\
\hline 9 & Polymer C & $1^{\text {st }}$ & 78 & 0.018 & 0.18 & 24 & 37 & ca. 94 \\
\hline 10 & Polymer C & $2^{\text {nd }}$ & 70 & 0.017 & 0.17 & 24 & 30 & ca. 94 \\
\hline 11 & Polymer C & $3^{\text {rd }}$ & 42 & 0.010 & 0.10 & 48 & 70 & ca. 94 \\
\hline 12 & Polymer C & $4^{\text {th }}$ & 36 & 0.009 & 0.09 & 48 & 38 & ca. 93 \\
\hline 13 & Polymer C & $5^{\text {th }}$ & 27 & 0.006 & 0.06 & $48^{d}$ & $70^{d}$ & ca. 90 \\
\hline 14 & Polymer C & $6^{\text {th }}$ & 20 & 0.005 & 0.05 & $48^{d}$ & $50^{d}$ & ca. 90 \\
\hline
\end{tabular}

${ }^{a}$ Reactions were carried out using 1,2-dihydronaphthalene (1 eq.), catalyst (as indicated) in dichloromethane ( $2.5 \mathrm{ml}$ for homogeneous reactions, $4 \mathrm{ml}$ for heterogeneous) in the presence of 4-PPNO ( 0.25 eq.), using $\mathrm{NaOCl}\left(5\right.$ eq.) as the terminal oxidant, at $0{ }^{\circ} \mathrm{C}$. ${ }^{b}$ The yield of epoxide was determined by gas chromatography (GC) using hexadecane as an internal standard. The estimated error limits are $\pm 5 \%{ }^{c}$ The enantiomeric excess was determined by the integration of peak areas in ${ }^{1} \mathrm{H}$ NMR spectra using the chiral shift reagent Eu(hfc) $)_{3}$ and the absolute configuration of the resultant epoxide, according to Katsuki et al., should be $1 S, 2 R .{ }^{32}{ }^{d}$ For these reactions the amount of solvent was reduced to $2 \mathrm{ml}$ (from $4 \mathrm{ml}$ ).<smiles>C1=Cc2ccccc2CC1</smiles>

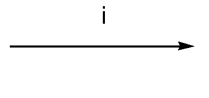

26

Scheme 5 Reagents: i) catalyst, $\mathrm{NaOCl}, 4-\mathrm{PPNO}$.

The first experiment using polymer A (the lowest loaded polymer) showed that its activity was lower than that of its homogeneous analogues $\mathbf{1 b}$ and $\mathbf{2}$. After $72 \mathrm{~h}$ the yield of epoxide was still only about $68 \%$ according to GC. The product was lost during evaporation of solvent, so the ee could not be measured.

In that first run with polymer $\mathbf{A}$, the quantity of polymer used was $83 \mathrm{mg}$, but it was difficult to recover all of the polymer after the reaction, primarily because of electrostatic attraction of the powder to the glass vessel and losses during filtration. Therefore, only $72 \mathrm{mg}$ were used in the repeat experiment. To ensure that the stoichiometry remained the same, the quantities of substrate, oxidant and donor ligand were also scaled down proportionately, but the quantity of solvent was not altered, so the concentrations were less, which could account for the lower rate of reaction than in the first use. However, the enantiomeric excess was about $90 \%$, more or less the same as that reported by Katsuki et al. (91\% ee). ${ }^{32}$

Polymer B differed from polymer $\mathbf{A}$ in its loading $(0.12 \mathrm{mmol}$ $\left.\mathrm{Mn} \mathrm{g}^{-1}\right)$ and in its anion $\left(\mathrm{PF}_{6}{ }^{-}\right.$rather than $\left.\mathrm{AcO}^{-}\right)$, but its activity was comparable. The enantioselectivity observed with this complex was excellent, similar to that produced by the homogeneous analogues $\mathbf{1 b}$ and $\mathbf{2}$. Furthermore, reuse of the polymer resulted in a yield and enantioselectivity that were similar to those obtained during the first use. The polymer was recovered and reused again and then again for a fourth time. Each time the amount of polymer available was less, because of sampling for analyses or physical losses, and since the amount of solvent was the same the reactions were slower. However, measurement of the ee of the product recovered at the end of each run suggested that there was only a very small loss of enantioselectivity, if any, in sequential runs.
A similar trend was observed in the first four runs with polymer C, the polymer with the highest loading. For the fifth use of the polymer a smaller reaction vessel and a reduced amount of solvent were used. The reaction then became faster. The sixth use was slower than the fifth because of the lower concentrations, but still not as slow as the fourth run had been in the larger reaction flask and with more solvent. (The size of the flask is important because some of the polymer tends to collect on the walls of the vessel above the solvent during stirring, and is not then in contact with the solution. In a larger vessel the amount that is out of contact becomes more significant.)

The ee values (Table 1) became progressively less reliable (because the spectra were noisier) for the smaller scale reactions, as the amount of available product became less. From the results it appeared that the initial enantioselectivity with polymer $\mathbf{C}$ was $\geq 94 \%$, comparable to that obtained with the free complexes $\mathbf{2}$ and 1a. It appeared that there might be a small drop in selectivity with successive re-uses of the polymer, but the ee was still at least $88 \%$ by the sixth use of the polymer. In view of the greater uncertainties for the reactions run with smaller quantities of polymer, it is even possible that there was no genuine reduction in ee at all.

AAS measurements of polymers $\mathbf{A}, \mathbf{B}$ and $\mathbf{C}$ after completion of the full sequence of uses showed that all three polymers possessed a slightly increased $\mathrm{Mn}$ proportion, $0.10 \mathrm{mmol} \mathrm{g}^{-1}$ for A, $0.13 \mathrm{mmol} \mathrm{g}^{-1}$ for $\mathbf{B}$, and $0.26 \mathrm{mmol} \mathrm{g}^{-1}$ for $\mathbf{C}$, consistent with anion-exchange to the lighter anion chloride, but not with loss of complex from the polymers. The IR spectra of the recovered polymers $\mathbf{A}, \mathbf{B}$ and $\mathbf{C}$ after use in the full set of reactions recorded in Table 1 were recorded. The broad absorption band at $840 \mathrm{~cm}^{-1}$ in polymers $\mathbf{B}$ and $\mathbf{C}$, assigned to the $\mathrm{PF}_{6}{ }^{-}$anion, had disappeared after several reuses. Other changes in the spectra of the recovered polymers $\mathbf{B}$ and $\mathbf{C}$ may suggest some hydrolysis of residual acyl chloride groups to give carboxylic acid groups. It did not seem likely that there had been significant cleavage of the ester groups linking the catalyst units to the polymers in view of the retention of Mn. Further evidence for this was sought by subjecting a model polymer to similar conditions. 
A model polymer was synthesised from 3-phenylpropanol and polystyrenecarbonyl chloride (22). This polymer was treated with $\mathrm{NaOCl}$ for 4 days under conditions similar to those used in the epoxidation reactions. There was little evidence for the presence of 3-phenylpropanol, suggesting that the ester link is stable to these conditions.

A further experiment was carried out to examine the stability of the homogeneous catalyst 2 . An epoxidation reaction was carried out using ten times the concentrations of substrate, 4-PPNO and $\mathrm{NaOCl}$ for the same amount of catalyst. After the reaction, the catalyst was recovered by column chromatography. The FT-IR spectrum showed major bands that were very similar to those of the original catalyst, but with additional bands due to 4-PPNO. The ee of the epoxide was also the same as in previous reactions, so again there seemed to be little to suggest significant decomposition of the catalyst.

In conclusion, therefore, we believe the salen unit of complexes $\mathbf{2 5}$ is relatively stable and the ester group linking it to the polymer remains largely intact during the epoxidation reactions. Therefore, the goal of producing a stable, recoverable, enantioselective catalyst has been achieved.

\section{Conclusions}

Compound 7, a new monosubstituted analogue of Katsuki's chiral salen ligand $\mathbf{2}$, has been successfully synthesised and converted into its Mn complexes, 1. Several complexes were attached to a polymer via an ester link using polystyrenecarbonyl chloride. All three samples were tested in epoxidation reactions with 1,2dihydronaphthalene using sodium hypochlorite as the oxidant and all were shown to be effective catalysts, giving high ee values. The reactions were much slower than with homogeneous analogues, in part a result of the more dilute conditions used in order to allow swelling of the polymer and stirring of the mixture, and in part due to the lower mobility of compounds within a polymer matrix.

All of the samples were recovered and re-used several times, resulting in the polymers' spending many days overall in contact with the basic reaction solutions. In all cases, the catalysts still gave high enantioselectivities even after six reuses in the case of polymer $\mathbf{C}$.

This is the first demonstration of the successful use of a polymer-supported Katsuki complex. By having just a single point of attachment to the polymer at a part of the ligand remote from the catalytic centre, possibilities for complications arising from multiple reacting species or from interference by the polymeric support at the active site were minimized. Indeed, the enantioselectivities of the supported catalysts were undiminished. The drop in rate of reaction in comparison to homogeneous counterparts is not surprising, because it is expected that the accessibility of the active sites would be diminished.

Katsuki et al. have developed a new (salen)Mn complex having a monocarboxylate group on the ethylenediamine moiety as a very efficient catalyst for the asymmetric epoxidation of 2,2dimethylchromene derivatives. ${ }^{2 c, 33}$ This complex exhibits a high turnover number (up to 9200) and enantioselectivity (up to $99 \%$ ee). It is also stable enough to be used over a 10 day period and can be recovered by chromatography. Such a complex may be an even better candidate for immobilisation.

\section{Experimental}

Details of the instrumentation used and sources and methods of purification of materials are reported in the ESI $\uparrow$.

Preparations of known compounds by literature procedures are reported in the ESI $\dagger$. Only the preparations of novel compounds are reported here.

Synthesis of (R)-6-bromo-2-hydroxy-2'-phenyl-1,1'-binaphthyl (11). A solution of $\mathbf{1 0}(7.75 \mathrm{~g}, 22.4 \mathrm{mmol})$ in dichloromethane $(300 \mathrm{ml})$ was cooled to $-78{ }^{\circ} \mathrm{C}$ in a cardice-acetone bath. A solution of bromine $(4.30 \mathrm{~g}, 1.40 \mathrm{ml}, 26.9 \mathrm{mmol})$ in dichloromethane $(200 \mathrm{ml})$ was added dropwise. The mixture was stirred at $-78{ }^{\circ} \mathrm{C}$ for $1 \mathrm{~h}$, allowed to warm to room temperature and then stirred for a further $15 \mathrm{~h}$ to give an orange solution. The solution was evaporated in vacuo to give a viscous orange gum. Purification by flash column chromatography $\left(\mathrm{SiO}_{2}\right.$, dichloromethane) gave a cream solid product $(9.14 \mathrm{~g}, 96 \%$ yield $) ;[a]_{\mathrm{D}}{ }^{20}+43.16$ ( c 2.88, $\left.\mathrm{CHCl}_{3}\right), \operatorname{mp~} 80-82^{\circ} \mathrm{C}$.

$\delta_{\mathrm{H}}\left(\mathrm{CDCl}_{3}\right) 4.94(\mathrm{~s}, 1 \mathrm{H}, \mathrm{OH}), 6.95(\mathrm{~d}, J=9 \mathrm{~Hz}, 1 \mathrm{H}), 7.05-7.09$ (m, $3 \mathrm{H}), 7.11-7.13(\mathrm{~m}, 2 \mathrm{H}), 7.14(\mathrm{~d}, J=9 \mathrm{~Hz}, 1 \mathrm{H}), 7.24$ (d, $J=8.5 \mathrm{~Hz}, 1 \mathrm{H}), 7.25(\mathrm{dd}, J=2,9 \mathrm{~Hz}, 1 \mathrm{H}), 7.33(\mathrm{dd}, J=7$, $8.5 \mathrm{~Hz}, 1 \mathrm{H}), 7.52(\mathrm{dd}, J=7,8 \mathrm{~Hz}, 1 \mathrm{H}), 7.66(\mathrm{~d}, J=9 \mathrm{~Hz}$, $1 \mathrm{H}), 7.69$ (d, $J=8.5 \mathrm{~Hz}, 1 \mathrm{H}), 7.91$ (d, $J=2 \mathrm{~Hz}, 1 \mathrm{H}), 7.97$ (d, $J=8 \mathrm{~Hz}, 1 \mathrm{H})$ and $8.07(\mathrm{~d}, J=8.5 \mathrm{~Hz}, 1 \mathrm{H}) ; \delta_{\mathrm{C}}\left(\mathrm{CDCl}_{3}\right) 117.0$, $118.0,118.3,126.0,126.5,126.8,127.1,127.3,3 \times 127.8,128.3$, $2 \times 128.5,128.6,128.9,129.6,129.7,129.8,130.0,132.6,132.9$, 133.2, 140.6, 141.6 and $151.4 ; \mathrm{m} / z$ (EI) $426\left(\mathrm{M}^{+}{ }^{81} \mathrm{Br}, 100 \%\right)$ and $424\left(\mathrm{M}^{+}{ }^{79} \mathrm{Br}, 100\right) ; m / z$ (CI) $444\left(\mathrm{M}+\mathrm{NH}_{4}{ }^{+{ }^{81}} \mathrm{Br}, 100 \%\right), 442$ $\left(\mathrm{M}^{+}+\mathrm{NH}_{4}{ }^{+79} \mathrm{Br}, 100\right)$ and 364 (70) (found: $\mathrm{M}^{+}{ }^{+7} \mathrm{Br}, 424.0463$. Calc. for $\mathrm{C}_{26} \mathrm{H}_{17} \mathrm{O}^{79} \mathrm{Br}$, 424.0463) (found: C, 72.87; H, 3.88. Calc. for $\mathrm{C}_{26} \mathrm{H}_{17} \mathrm{OBr}, \mathrm{C}, 73.42 ; \mathrm{H}, 4.03 \%$ ).

Synthesis of $(R)$-methyl-3-(2-hydroxy-2'-phenyl-1,1'-binaphthyl6-yl)acrylate (12). To a mixture of $11(11.9 \mathrm{~g}, 28.0 \mathrm{mmol})$, anhydrous sodium acetate $(2.76 \mathrm{~g}, 33.6 \mathrm{mmol})$, palladium acetate $(63 \mathrm{mg}, 0.28 \mathrm{mmol})$ and tris $(o$-tolyl)phosphine $(341 \mathrm{mg}$, $1.12 \mathrm{mmol})$ in dry DMF $(80 \mathrm{ml})$ under nitrogen was added methyl acrylate $(2.89 \mathrm{~g}, 3.1 \mathrm{ml}, 33.6 \mathrm{mmol})$ and the mixture was heated at $150{ }^{\circ} \mathrm{C}$ (oil bath) for $4 \mathrm{~h}$. After the reaction was completed, it was quenched with water $(150 \mathrm{ml})$ and extracted with ether $(150 \mathrm{ml})$. The extract was washed with water $(2 \times 60 \mathrm{ml})$, dried over $\mathrm{MgSO}_{4}$ and concentrated in vacuo to give a cream solid product $(11.44 \mathrm{~g}$, $95 \%$ yield).

$\delta_{\mathrm{H}}\left(\mathrm{CDCl}_{3}\right) 3.80(\mathrm{~s}, 3 \mathrm{H}), 5.02(\mathrm{~s}, 1 \mathrm{H}, \mathrm{OH}), 6.42\left(\mathrm{~d}, J_{\text {trans }}=16 \mathrm{~Hz}\right.$, $1 \mathrm{H}), 7.09-7.14(\mathrm{~m}, 6 \mathrm{H}), 7.16(\mathrm{~d}, J=9 \mathrm{~Hz}, 1 \mathrm{H}), 7.27(\mathrm{~d}, J=$ $8.5 \mathrm{~Hz}, 1 \mathrm{H}), 7.34(\mathrm{dd}, J=7,8.5 \mathrm{~Hz}, 1 \mathrm{H}), 7.39(\mathrm{dd} J=9 \mathrm{~Hz}$, $1 \mathrm{H}), 7.52(\mathrm{dd}, J=7,8.1 \mathrm{~Hz}, 1 \mathrm{H}), 7.72(\mathrm{~d}, J=8.5 \mathrm{~Hz}, 1 \mathrm{H}), 7.78$ $\left(\mathrm{d}, J_{\text {trans }}=16 \mathrm{~Hz}, 1 \mathrm{H}\right), 7.79(\mathrm{~d}, J=9 \mathrm{~Hz}, 1 \mathrm{H}), 7.86(\mathrm{~s}, 1 \mathrm{H}), 7.99$ $(\mathrm{d}, J=8 \mathrm{~Hz}, 1 \mathrm{H})$ and $8.05(\mathrm{~d}, J=8.5 \mathrm{~Hz}, 1 \mathrm{H}) ; \delta_{\mathrm{C}}\left(\mathrm{CDCl}_{3}\right) 51.7$, $116.7,118.0,118.2,124.3,125.7,126.0,126.5,127.1,2 \times 127.3$, $127.8,128.3,128.4,3 \times 128.5,128.6,129.3,129.6,130.3,130.6$, 133.0, 133.2, 135.1, 140.6, 141.6, 145.0, 152.4 and 167.4; $\mathrm{m} / \mathrm{z}$ (EI) $430\left(\mathrm{M}^{+}, 100 \%\right), 204(45)$ and $77(25) ; \mathrm{m} / z(\mathrm{CI}) 448\left(\mathrm{M}^{+}+\mathrm{NH}_{4}\right.$, $5 \%)$ and $431\left(\mathrm{MH}^{+}, 100\right)$ (found: $\mathrm{M}^{+}, 430.1556$. Calc. for $\mathrm{C}_{30} \mathrm{H}_{22} \mathrm{O}_{3}$, 430.1569) (found: $\mathrm{C}, 83.74 ; \mathrm{H}, 5.12$. Calc. for $\mathrm{C}_{30} \mathrm{H}_{22} \mathrm{O}_{3}, \mathrm{C}, 83.70$; $\mathrm{H}, 5.15 \%)$.

Synthesis of ( $R$ )-methyl-3-(2-hydroxy-2'-phenyl-1,1'-binaphthyl6-yl)propanoate (13). To magnesium turnings $(9.27 \mathrm{~g}, 381 \mathrm{mmol}$, 
pre-dried in an oven at $\left.120{ }^{\circ} \mathrm{C}\right)$ in dry methanol $(300 \mathrm{ml})$ under nitrogen was added a solution of $12(3.90 \mathrm{~g}, 9.07 \mathrm{mmol})$ in dry THF $(60 \mathrm{ml})$, and the mixture was heated to $80{ }^{\circ} \mathrm{C}$ (oil bath) for $3.5 \mathrm{~h}$, by which time the reaction was complete. The mixture was cooled to room temperature and $3 \mathrm{M} \mathrm{HCl}$ was added carefully until the excess magnesium dissolved. The mixture was then extracted with ether $(800 \mathrm{ml})$, and the extract was washed with brine $(2 \times$ $200 \mathrm{ml}$ ), dried over $\mathrm{MgSO}_{4}$ and concentrated in vacuo to give a cream powder $(3.49 \mathrm{~g}, 89 \%$ yield). Purification by column chromatography $\left(\mathrm{SiO}_{2}\right.$, toluene-ether $\left.5: 1\right)$ gave a cream solid $(2.08 \mathrm{~g}, 61 \%) ;[a]_{\mathrm{D}}{ }^{20}+34.12\left(c 2.70, \mathrm{CHCl}_{3}\right), \mathrm{mp} 66-68{ }^{\circ} \mathrm{C}$.

$\delta_{\mathrm{H}}\left(\mathrm{CDCl}_{3}\right) 2.65(\mathrm{t}, J=8 \mathrm{~Hz}, 2 \mathrm{H}), 3.01(\mathrm{t}, J=8 \mathrm{~Hz}, 2 \mathrm{H}), 3.61$ (s, $3 \mathrm{H}), 4.91$ (bs, $1 \mathrm{H}, \mathrm{OH}), 7.00$ (d, $J=9 \mathrm{~Hz}, 1 \mathrm{H}), 7.03-7.06$ $(\mathrm{m}, 4 \mathrm{H}), 7.10(\mathrm{~d}, J=9 \mathrm{~Hz}, 1 \mathrm{H}), 7.12-7.16(\mathrm{~m}, 2 \mathrm{H}), 7.28-7.31$ $(\mathrm{m}, 2 \mathrm{H}), 7.50(\mathrm{dd}, J=6,8 \mathrm{~Hz}, 1 \mathrm{H}), 7.55$ (bs, $1 \mathrm{H}), 7.68(\mathrm{~d}, J=$ $9 \mathrm{~Hz}, 1 \mathrm{H}), 7.70(\mathrm{~d}, J=8.5 \mathrm{~Hz}, 1 \mathrm{H}), 7.96(\mathrm{~d}, J=8 \mathrm{~Hz}, 1 \mathrm{H})$ and $8.05(\mathrm{~d}, J=8.5 \mathrm{~Hz}, 1 \mathrm{H}) ; \delta_{\mathrm{C}}\left(\mathrm{CDCl}_{3}\right) 30.7,35.5,51.6,117.3,117.6$, $125.2,126.3,126.4,126.6,126.9,127.1,2 \times 127.6,127.7,128.1$, $128.2,2 \times 128.6,128.8,129.0,129.3,129.4,132.8,133.1,133.2$, $135.1,140.8,141.5,150.7$ and $173.5 ; \mathrm{m} / z(\mathrm{EI}) 432\left(\mathrm{M}^{+}, 100 \%\right)$ and 359 (70); $m / z$ (CI) $450\left(\mathrm{M}+\mathrm{NH}_{4}{ }^{+}, 100 \%\right.$ ) (found: $\mathrm{M}^{+}, 432.1722$. Calc. for $\mathrm{C}_{30} \mathrm{H}_{24} \mathrm{O}_{3}, 432.1725$ ) (found: $\mathrm{C}, 83.47 ; \mathrm{H}, 5.71$. Calc. for $\mathrm{C}_{30} \mathrm{H}_{24} \mathrm{O}_{3}, \mathrm{C}, 83.31 ; \mathrm{H}, 5.59 \%$ ).

Synthesis of (R)-2-hydroxy-6-(3-hydroxypropyl)-2' -phenyl-1,1' binaphthyl (14). $\mathrm{LiAlH}_{4}(1.07 \mathrm{~g}, 28.3 \mathrm{mmol})$ in dry THF $(150 \mathrm{ml})$ was stirred for $10 \mathrm{~min}$ at room temperature. A solution of $\mathbf{1 3}$ $(6.30 \mathrm{~g}, 14.6 \mathrm{mmol})$ in dry THF $(150 \mathrm{ml})$ was added over a period of $5 \mathrm{~min}$ and then the mixture was refluxed gently for $20 \mathrm{~min}$. A colourless gelatinous precipitate appeared immediately. When the reaction was completed, ethyl acetate $(100 \mathrm{ml})$ was added to destroy the excess $\mathrm{LiAlH}_{4}$, followed by hydrochloric acid (3 M, $30 \mathrm{ml})$. The mixture was extracted with ethyl acetate $(300 \mathrm{ml})$ and the extract was washed with water $(2 \times 100 \mathrm{ml})$, dried over $\mathrm{MgSO}_{4}$ and concentrated in vacuo to give a cream solid. Crystallisation from chloroform gave a white powder $(4.24 \mathrm{~g}, 72 \%$ yield $) ;[a]_{\mathrm{D}}{ }^{20}$ $+54.21\left(\mathrm{c} \mathrm{2} 2.87, \mathrm{CHCl}_{3}\right), \mathrm{mp} 162-164{ }^{\circ} \mathrm{C}$.

$\delta_{\mathrm{H}}\left(\mathrm{CDCl}_{3}\right) 1.25(\mathrm{~s}, 1 \mathrm{H}, \mathrm{OH}), 1.91(\mathrm{~m}, 2 \mathrm{H}), 2.76(\mathrm{t}, J=8 \mathrm{~Hz}$, $2 \mathrm{H}), 3.65(\mathrm{t}, J=6 \mathrm{~Hz}, 2 \mathrm{H}), 4.88(\mathrm{~s}, 1 \mathrm{H}, \mathrm{OH}), 7.00(\mathrm{~d}, J=8.5 \mathrm{~Hz}$, $1 \mathrm{H}), 7.02-7.07(\mathrm{~m}, 4 \mathrm{H}), 7.10(\mathrm{~d}, J=8.9 \mathrm{~Hz}, 1 \mathrm{H}), 7.12-7.15(\mathrm{~m}$, $2 \mathrm{H}), 7.29-7.33(\mathrm{~m}, 2 \mathrm{H}), 7.50(\mathrm{dd}, J=5.5,8 \mathrm{~Hz}, 1 \mathrm{H}), 7.55$ (bs, $1 \mathrm{H}), 7.68(\mathrm{~d}, J=9 \mathrm{~Hz}, 1 \mathrm{H}), 7.69(\mathrm{~d}, J=8.5 \mathrm{~Hz}, 1 \mathrm{H}), 7.96(\mathrm{~d}$, $J=8 \mathrm{~Hz}, 1 \mathrm{H})$ and $8.07(\mathrm{~d}, J=8.5 \mathrm{~Hz}, 1 \mathrm{H}) ; \delta_{\mathrm{C}}\left(\mathrm{CDCl}_{3}\right) 31.8,33.9$, $62.4,117.2,117.6,125.1,2 \times 126.4,126.6,126.9,127.1,2 \times 127.7$, $127.9,128.2,128.5,2 \times 128.6,128.7,128.8,129.2,129.3,132.7$, 133.2, 136.4, 140.8, 141.5 and 150.5; $\mathrm{m} / \mathrm{z}$ (EI) $404\left(\mathrm{M}^{+}, 100 \%\right), 360$ (35) and 359 (70); $m / z(\mathrm{CI}) 422\left(\mathrm{M}+\mathrm{NH}_{4}{ }^{+}, 100 \%\right)$ (found: $\mathrm{M}^{+}$, 404.1784. Calc. for $\mathrm{C}_{29} \mathrm{H}_{24} \mathrm{O}_{2}$, 404.1776) (found: C, 86.30; H, 5.66. Calc. for $\mathrm{C}_{29} \mathrm{H}_{24} \mathrm{O}_{2}, \mathrm{C}, 86.11 ; \mathrm{H}, 5.98 \%$ ).

Synthesis of (R)-2-(methoxymethoxy)-6-[3-(methoxymethoxy)propyl]-2'-phenyl-1,1'-binaphthyl (15). To a solution of 14 (3.82 $\mathrm{g}, 9.46 \mathrm{mmol})$ in a mixture of dry dichloromethane $(120 \mathrm{ml})$ and dry THF $(15 \mathrm{ml})$ under nitrogen was added $N, N$-diisopropylethylamine $(13.65 \mathrm{~g}, 17.0 \mathrm{ml}, 94.6 \mathrm{mmol})$ and chloromethyl methyl ether $(9.88 \mathrm{~g}, 7.2 \mathrm{ml}, 94.6 \mathrm{mmol})$. The mixture was stirred for $24 \mathrm{~h}$ at room temperature, quenched with water $(160 \mathrm{ml})$, and extracted with dichloromethane $(30 \mathrm{ml})$. The extract was washed with water $(2 \times 80 \mathrm{ml})$, dried over $\mathrm{MgSO}_{4}$ and concentrated in vacuo. Purification by column chromatography on neutral alumina (elution with hexane-ether $5: 4$ ) gave $\mathbf{1 5}$ as a cream viscous product $(2.79 \mathrm{~g}, 60 \%$ yield $) ;[\alpha]_{\mathrm{D}}{ }^{20}+60.14$ (c 0.69 , $\left.\mathrm{CHCl}_{3}\right)$.

$\delta_{\mathrm{H}}\left(\mathrm{CDCl}_{3}\right) 1.95(\mathrm{~m}, 2 \mathrm{H}), 2.78(\mathrm{t}, J=8 \mathrm{~Hz}, 2 \mathrm{H}), 3.08(\mathrm{~s}, 3 \mathrm{H})$, $3.35(\mathrm{~s}, 3 \mathrm{H}), 3.54(\mathrm{t}, J=6 \mathrm{~Hz}, 2 \mathrm{H}), 4.62(\mathrm{~s}, 2 \mathrm{H}), 4.73$ (d, $J=$ $7 \mathrm{~Hz}, 1 \mathrm{H}), 4.87$ (d, $J=7 \mathrm{~Hz}, 1 \mathrm{H}), 7.00-7.06$ (m, $5 \mathrm{H}), 7.10-7.15$ (m, $2 \mathrm{H}), 7.22-7.26(\mathrm{~m}, 2 \mathrm{H}), 7.39(\mathrm{~d}, J=9 \mathrm{~Hz}, 1 \mathrm{H}), 7.43(\mathrm{~m}, 1 \mathrm{H})$, 7.57 (bs, $1 \mathrm{H}), 7.66(\mathrm{~d}, J=8.5 \mathrm{~Hz}, 1 \mathrm{H}), 7.73(\mathrm{~d}, J=9 \mathrm{~Hz}, 1 \mathrm{H})$, $7.93(\mathrm{~d}, J=8 \mathrm{~Hz}, 1 \mathrm{H})$ and $8.00(\mathrm{~d}, J=8.5 \mathrm{~Hz}, 1 \mathrm{H}) ; \delta_{\mathrm{C}}\left(\mathrm{CDCl}_{3}\right)$ 31.0, 32.2, 55.2, 55.6, 67.1, 95.2, 96.4, 116.4, 122.9, 125.6, 125.8, $126.2,126.4,126.5,126.8,2 \times 127.3,127.9,2 \times 128.0,128.2,2 \times$ $128.8,128.9,129.5,131.9,132.7,132.9,133.1,137.1,139.9,142.0$ and 152.4; $\mathrm{m} / \mathrm{z}(\mathrm{EI}) 492\left(\mathrm{M}^{+}, 30 \%\right)$ and $45(100) ; \mathrm{m} / \mathrm{z}$ (CI) 510 $\left(\mathrm{M}+\mathrm{NH}_{4}{ }^{+}, 100 \%\right)$ and 60 (100) (found: $\mathrm{M}^{+}, 492.2306$. Calc. for $\left.\mathrm{C}_{33} \mathrm{H}_{32} \mathrm{O}_{4}, 492.2301\right)$.

Synthesis of $(R)-3-f o r m y l-2-(m e t h o x y m e t h o x y)-6-[3-(m e t h o x y-$ methoxy)propyl]-2'-phenyl-1,1'-binaphthyl (16). To a solution of $\mathbf{1 5}(2.02 \mathrm{~g}, 4.11 \mathrm{mmol})$ in dry THF $(50 \mathrm{ml})$ at $-78^{\circ} \mathrm{C}$ under nitrogen was added a solution of tert-butyllithium $(1.7 \mathrm{M}$ in pentane, $2.90 \mathrm{ml}, 4.93 \mathrm{mmol}$ ) by syringe and the mixture was stirred for $3 \mathrm{~h}$ at $-78^{\circ} \mathrm{C} . N, N$-Dimethylformamide ( $901 \mathrm{mg}, 0.95 \mathrm{ml}, 12.3 \mathrm{mmol}$ ) was added and the reaction mixture was allowed to warm to room temperature and stirred for $2 \mathrm{~h}$, then quenched with aqueous $\mathrm{NH}_{4} \mathrm{Cl}(100 \mathrm{ml})$, and extracted with ethyl acetate $(300 \mathrm{ml})$. The extract was washed with aqueous $\mathrm{NaHCO}_{3}(100 \mathrm{ml})$ and brine $(2 \times 100 \mathrm{ml})$, dried over $\mathrm{Na}_{2} \mathrm{SO}_{4}$ and concentrated in vacuo to give a viscous product. Purification by column chromatography on neutral alumina gave recovered $\mathbf{1 5}$ (elution with hexane-ether $5: 5)$ as a viscous product ( $808 \mathrm{mg}, 40 \%)$ and then $\mathbf{1 6}$ (methanol) as a viscous product $(1.28 \mathrm{~g}, 60 \%$ yield $) ;[\alpha]_{\mathrm{D}}{ }^{20}+9.96\left(c 1.17, \mathrm{CHCl}_{3}\right)$.

$\delta_{\mathrm{H}}\left(\mathrm{CDCl}_{3}\right) 1.90(\mathrm{~m}, 2 \mathrm{H}), 2.76(\mathrm{t}, J=7 \mathrm{~Hz}, 2 \mathrm{H}), 2.78(\mathrm{~s}, 3 \mathrm{H})$, 3.29 (s, $3 \mathrm{H}), 3.49$ (t, $J=7 \mathrm{~Hz}, 2 \mathrm{H}), 4.32$ (d, $J=6 \mathrm{~Hz}, 1 \mathrm{H}), 4.50$ $(\mathrm{d}, J=6 \mathrm{~Hz}, 1 \mathrm{H}), 4.55(\mathrm{~s}, 2 \mathrm{H}), 6.89-7.07(\mathrm{~m}, 5 \mathrm{H}), 7.11-7.18(\mathrm{~m}$, $3 \mathrm{H}), 7.23(\mathrm{dd}, J=7,8.5 \mathrm{~Hz}, 1 \mathrm{H}), 7.40(\mathrm{dd}, J=7,8 \mathrm{~Hz}, 1 \mathrm{H}), 7.59$ $(\mathrm{d}, J=9 \mathrm{~Hz}, 1 \mathrm{H}), 7.68$ (bs, $1 \mathrm{H}), 7.88(\mathrm{~d}, J=8 \mathrm{~Hz}, 1 \mathrm{H}), 7.96$ (d, $J=9 \mathrm{~Hz}, 1 \mathrm{H}), 8.27(\mathrm{~s}, 1 \mathrm{H})$ and $10.24(\mathrm{~s}, 1 \mathrm{H}) ; \delta_{\mathrm{C}}\left(\mathrm{CDCl}_{3}\right) 30.9$, $32.2,55.2,56.8,66.9,96.5,99.7,125.9,126.5,126.7,2 \times 126.8$, $2 \times 127.5,128.1,128.5,2 \times 128.6,2 \times 128.7,128.8,129.1,129.7$, $130.4,130.8,130.9,132.7,133.2,136.2,139.4,140.8,141.5,152.7$ and 191.1; $m / z(\mathrm{EI}) 520\left(\mathrm{M}^{+}, 55 \%\right), 476(25), 326(50), 215(40)$ and $77(100) ; m / z(C I) 538\left(\mathrm{M}+\mathrm{NH}_{4}{ }^{+}, 10 \%\right), 446(30), 445(100)$ and 58 (100) (found: $\mathrm{M}^{+}, 520.2255$. Calc. for $\mathrm{C}_{34} \mathrm{H}_{32} \mathrm{O}_{5}, 520.2250$ ) (found: $\mathrm{C}, 78.76 ; \mathrm{H}, 6.14$. Calc. for $\mathrm{C}_{34} \mathrm{H}_{32} \mathrm{O}_{5}$ : C, 78.44; H, 6.20\%).

Synthesis of $(R)$-3-formyl-2-hydroxy-6-(3-hydroxypropyl)-2'phenyl-1,1'-binaphthyl (6). To a solution of 16 (400 mg, $0.77 \mathrm{mmol})$ in dry dichloromethane $(10 \mathrm{ml})$ containing 4 Å molecular sieves $(2.51 \mathrm{~g})$ under nitrogen was added bromotrimethylsilane $(1.0 \mathrm{ml}, 7.70 \mathrm{mmol})$. The mixture was stirred for $1 \mathrm{~h}$ at room temperature. It was then quenched with aqueous $\mathrm{NaHCO}_{3}(40 \mathrm{ml})$ and stirred for $4 \mathrm{~h}$ until the solvent became clear, and then extracted with dichloromethane $(50 \mathrm{ml})$. The extract was washed with water $(30 \mathrm{ml})$ and brine $(30 \mathrm{ml})$, dried over $\mathrm{MgSO}_{4}$ and concentrated in vacuo to give a yellow product. Purification by column chromatography $\left(\mathrm{SiO}_{2}\right.$, hexane-ether, $\left.1.5: 5\right)$ gave 6 as a yellow solid (306 mg, 92\% yield); $[\alpha]_{\mathrm{D}}{ }^{20}-23.60\left(c 0.79, \mathrm{CHCl}_{3}\right.$ ), $\mathrm{mp} 88-90{ }^{\circ} \mathrm{C}$.

$\delta_{\mathrm{H}}\left(\mathrm{CDCl}_{3}\right) 1.36(\mathrm{~s}, \mathrm{OH}, 1 \mathrm{H}), 1.83(\mathrm{~m}, 2 \mathrm{H}), 2.69(\mathrm{t}, J=8 \mathrm{~Hz}$, $2 \mathrm{H}), 3.59(\mathrm{t}, J=6 \mathrm{~Hz}, 2 \mathrm{H}), 6.94-6.98(\mathrm{~m}, 4 \mathrm{H}), 7.09(\mathrm{~d}, J=9 \mathrm{~Hz}$, 
$1 \mathrm{H}), 7.10-7.16(\mathrm{~m}, 2 \mathrm{H}), 7.17(\mathrm{~d}, J=9 \mathrm{~Hz}, 1 \mathrm{H}), 7.22(\mathrm{dd}, J=7$, $8 \mathrm{~Hz}, 1 \mathrm{H}), 7.40$ (dd, $J=7,8 \mathrm{~Hz}, 1 \mathrm{H}), 7.55$ (bs, $1 \mathrm{H}), 7.57$ (d, $J=$ $8.5 \mathrm{~Hz}, 1 \mathrm{H}), 7.89(\mathrm{~d}, J=8 \mathrm{~Hz}, 1 \mathrm{H}), 7.96(\mathrm{~d}, J=8.5 \mathrm{~Hz}, 1 \mathrm{H}), 8.00$ $(\mathrm{s}, 1 \mathrm{H}), 9.99(\mathrm{~s}, 1 \mathrm{H})$ and $10.31(\mathrm{~s}, 1 \mathrm{H}, \mathrm{OH}) ; \delta_{\mathrm{C}}\left(\mathrm{CDCl}_{3}\right)$ 31.6, 33.6, $62.1,121.1,121.5,125.5,125.8,126.1,126.5,126.6,127.3,2 \times$ $127.4,127.9,128.2,128.3,128.5,2 \times 128.6,129.9,131.9,132.6$, $132.9,136.3,137.3,137.5,140.6,141.8,153.1$ and $196.9 ; \mathrm{m} / z(\mathrm{EI})$ $432\left(\mathrm{M}^{+}, 100 \%\right), 387$ (30), 326 (40), 77 (30) and 41 (30); (CI) 450 $\left(\mathrm{M}+\mathrm{NH}_{4}^{+}, 20 \%\right), 433$ (40), 58 (70) and 44 (100) (found: $\mathrm{M}^{+}$, 432.1720. Calc. for $\left.\mathrm{C}_{30} \mathrm{H}_{24} \mathrm{O}_{3}, 432.1725\right)$.

Synthesis of the unsymmetrical chiral salen ligand, $N-I(R)-(2-$ hydroxy-2' -phenyl-1,1' -binaphthyl-3-ylmethylene) $]-N^{\prime}-[(R)-2$-hydroxy-6-(3-hydroxypropyl)-2'-phenyl-1,1'-binaphthyl-3-ylmethylene]-

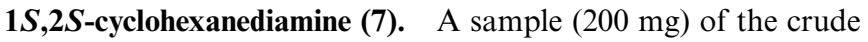
product from the above reaction, containing compound $\mathbf{5}$ ( $\mathrm{ca}$. $126 \mathrm{mg}, 0.27 \mathrm{mmol}$ ) and 19a (ca. $74 \mathrm{mg}, 0.09 \mathrm{mmol}$ ), was dissolved in a mixture of methanol $(10 \mathrm{ml})$ and dichloromethane $(10 \mathrm{ml})$. Compound 6 (130 mg, $0.30 \mathrm{mmol})$ was added and the reaction mixture was stirred for $3 \mathrm{~h}$ at room temperature. The solvent was removed in vacuo to give a yellow powder, $330 \mathrm{mg}$. Purification by column chromatography $\left(\mathrm{SiO}_{2}\right.$, hexane-ether $1: 5$ then methanol) gave compound 19a (100 mg), compound 7 (200 mg, 75\% yield based on 6, 84\% based on 5), and compound $\mathbf{1 9 b}(30 \mathrm{mg})$.

Alternative procedure for synthesis of the unsymmetrical chiral salen ligand (7). To a solution of $(1 S, 2 S)$-diaminocyclohexane $(4,44.2 \mathrm{mg}, 0.39 \mathrm{mmol})$ in dichloromethane $(25 \mathrm{ml})$ containing $4 \AA$ molecular sieves $(500 \mathrm{mg})$ at room temperature under nitrogen was added a solution of $\mathbf{3}(140.6 \mathrm{mg}, 0.38 \mathrm{mmol})$ in dichloromethane $(15 \mathrm{ml})$ dropwise over $1 \mathrm{~h}$ by means of a dropping funnel. After the addition was completed, the mixture was stirred for an additional $1 \mathrm{~h}$. A solution of $6(162.4 \mathrm{mg}, 0.38 \mathrm{mmol})$ in dichloromethane $(10 \mathrm{ml})$ was added and the reaction mixture was stirred for $24 \mathrm{~h}$ at room temperature and then filtered. The filtrate was concentrated in vacuo to give a yellow powder, $310 \mathrm{mg}$. The product was purified by column chromatography on silica gel (elution with pet. $40-60^{\circ}-$ ether $1: 5$, then methanol). The product mixture was not soluble in pet. $40-60^{\circ}$-ether, so it was first dissolved in dichloromethane, one equivalent of $4(0.38 \mathrm{mmol})$ was added, then silica $(5 \mathrm{mg})$, and the solvent was removed. The dry silica was added to the top of a pre-prepared silica column, which was then eluted with pet. 40$60^{\circ}$-ether $(1: 5)$ then methanol. Evaporation of the appropriate fractions gave 19a (109 mg, 35\% yield; mp $\left.300{ }^{\circ} \mathrm{C}\right), 7(134 \mathrm{mg}, 40 \%$ yield; $\mathrm{mp} 154{ }^{\circ} \mathrm{C}$ ) and $19 \mathrm{~b}$ (66 mg, 19\% yield; mp 200-202 ${ }^{\circ} \mathrm{C}$ ).

$N, N^{\prime}$-Bis $[(R)$-(2-hydroxy-2' -phenyl-1,1' -binaphthyl-3-ylmethylene) $-1 S, 2 S$-cyclohexanediamine (19a). $\delta_{\mathrm{H}}\left(\mathrm{CDCl}_{3}\right) 1.34(\mathrm{~m}, 2 \mathrm{H})$, $1.66(\mathrm{~m}, 2 \mathrm{H}), 1.78(\mathrm{~m}, 2 \mathrm{H}), 1.93(\mathrm{~m}, 2 \mathrm{H}), 3.17(\mathrm{~m}, 2 \mathrm{H}), 6.01(\mathrm{t}$, $J=7 \mathrm{~Hz}, 2 \mathrm{H}), 6.21$ (app. t, $J=7 \mathrm{~Hz}, 4 \mathrm{H}), 6.87$ (d, $J=8.5 \mathrm{~Hz}$, $2 \mathrm{H}), 6.90\left(\mathrm{~m}, 2 \mathrm{H}, \mathrm{H}_{7}\right), 7.01-7.10(\mathrm{~m}, 5 \mathrm{H}), 7.13-7.17(\mathrm{~m}, 3 \mathrm{H})$, $7.21(\mathrm{~m}, 2 \mathrm{H}), 7.26-7.30$ (m, $4 \mathrm{H}), 7.37$ (dd, $J=7,8 \mathrm{~Hz}, 2 \mathrm{H}), 7.57$ $(\mathrm{d}, J=8.5 \mathrm{~Hz}, 2 \mathrm{H}), 7.87(\mathrm{~d}, J=8 \mathrm{~Hz}, 2 \mathrm{H}), 7.94(\mathrm{~d}, J=8.5 \mathrm{~Hz}$, $2 \mathrm{H}), 8.17(\mathrm{~s}, 2 \mathrm{H})$ and $13.10(\mathrm{~s}, 2 \mathrm{H}, 2 \mathrm{OH}) ; \delta_{\mathrm{C}}\left(\mathrm{CDCl}_{3}\right) 24.1,32.5$, $73.2,119.8,120.0,123.1,124.6,125.7,126.3,126.4,126.5,127.1$, $2 \times 127.3,128.0,4 \times 128.1,128.3,128.6,131.2,132.9,133.0$, $133.4,134.7,140.3,141.8,154.9$ and $165.2 ; \mathrm{m} / \mathrm{z}(\mathrm{FAB}) 827\left(\mathrm{MH}^{+}\right.$, $72 \%$ ) and 149 (100) (found: $\mathrm{MH}^{+}, 827.3626$. Calc. for $\mathrm{C}_{60} \mathrm{H}_{47} \mathrm{O}_{2} \mathrm{~N}_{2}$, 827.3637); $v_{\max } / \mathrm{cm}^{-1}$ (KBr) 3359 (broad, O-H), 2927, 2856 and $1631(\mathrm{C}=\mathrm{N})$.
Compound 7. $\delta_{\mathrm{H}}\left(\mathrm{CDCl}_{3}\right) 1.35(\mathrm{~m}, 2 \mathrm{H}), 1.50$ (bs, $\left.1 \mathrm{H}, \mathrm{OH}\right)$, 1.6-1.7 (m, 4 H), 1.78 (m, 2 H), 1.94 (m, 2 H), 2.45 (m, 2 H), 3.15 $(\mathrm{m}, 2 \mathrm{H}), 3.41(\mathrm{~m}, 2 \mathrm{H}), 6.02(\mathrm{t}, J=7 \mathrm{~Hz}, 1 \mathrm{H}), 6.06(\mathrm{t}, J=7 \mathrm{~Hz}$, $1 \mathrm{H}), 6.20(\mathrm{t}, J=8 \mathrm{~Hz}, 2 \mathrm{H}), 6.28(\mathrm{t}, J=8 \mathrm{~Hz}, 2 \mathrm{H}), 6.79(\mathrm{~d}, J=$ $9 \mathrm{~Hz}, 2 \mathrm{H}), 6.82-6.93(\mathrm{~m}, 4 \mathrm{H}), 7.02(\mathrm{~m}, 1 \mathrm{H}), 7.07$ (d, $J=8 \mathrm{~Hz}$, $2 \mathrm{H}), 7.10(\mathrm{~d}, J=8 \mathrm{~Hz}, 2 \mathrm{H}), 7.15(\mathrm{~s}, 1 \mathrm{H}, \mathrm{CH}=\mathrm{N}), 7.16(\mathrm{~s}, 1 \mathrm{H})$, $7.21(\mathrm{~m}, 3 \mathrm{H}), 7.28(\mathrm{~m}, 2 \mathrm{H}), 7.37(\mathrm{~m}, 2 \mathrm{H}), 7.56(\mathrm{~d}, J=8 \mathrm{~Hz}, 1 \mathrm{H})$, $7.57(\mathrm{~d}, J=8 \mathrm{~Hz}, 1 \mathrm{H}), 7.86(\mathrm{~d}, J=8 \mathrm{~Hz}, 1 \mathrm{H}), 7.87(\mathrm{~d}, J=8 \mathrm{~Hz}$, $1 \mathrm{H}), 7.93(\mathrm{~d}, J=8 \mathrm{~Hz}, 1 \mathrm{H}), 7.94(\mathrm{~d}, J=8 \mathrm{~Hz}, 1 \mathrm{H}), 8.14(\mathrm{~s}, 2 \mathrm{H})$ and $13.00(\mathrm{bs}, 2 \mathrm{H}, 2 \mathrm{OH}) ; \delta_{\mathrm{C}}\left(\mathrm{CDCl}_{3}\right) 2 \times 24.1,31.4,2 \times 32.5$, $33.5,62.1,2 \times 73.2,119.8,119.9,120.0,122.9,2 \times 124.6,125.5$, $125.7,126.2,126.3,2 \times 126.4,2 \times 126.5,2 \times 127.0,127.2,4 \times$ $127.4,127.9,128.0,4 \times 128.1,4 \times 128.2,2 \times 128.3,128.6,129.2$, $2 \times 131.3,132.8,2 \times 132.9,2 \times 133.0,133.3,133.4,134.6,136.1$, $2 \times 140.3,2 \times 141.9,154.4,154.9,165.3$ and $165.4 ; \mathrm{m} / z(\mathrm{FAB})$ $885\left(\mathrm{MH}^{+}, 30 \%\right), 884\left(\mathrm{M}^{+}, 13\right), 286(58), 178.1(54), 165.1(80)$ and 153 (100) (found: $\mathrm{M}^{+}, 884.3961$. Calc. for $\mathrm{C}_{63} \mathrm{H}_{52} \mathrm{O}_{3} \mathrm{~N}_{2}, 884.3978$ ); $v_{\max } / \mathrm{cm}^{-1}(\mathrm{KBr}) 3359$ (broad, O-H), 2927, 2856 and $1631(\mathrm{C}=\mathrm{N})$.

$N, N^{\prime}$ - Bis $[(R)-2$-hydroxy-6-(3-hydroxypropyl)-2' - phenyl-1,1' binaphthyl-3-ylmethylene]-1S,2S-cyclohexanediamine (19b). $\delta_{\mathrm{H}}\left(\mathrm{CDCl}_{3}\right) 1.38(2 \mathrm{H}, \mathrm{m}), 1.5-1.6(\mathrm{~m}, 4 \mathrm{H}), 1.64(\mathrm{~m}, 4 \mathrm{H}), 1.80(\mathrm{~m}$, $2 \mathrm{H}), 1.95(\mathrm{~m}, 2 \mathrm{H}), 2.47(\mathrm{~m}, 4 \mathrm{H}), 3.19(\mathrm{~m}, 2 \mathrm{H}), 3.42(\mathrm{~m}, 4 \mathrm{H})$, $6.00(\mathrm{t}, J=8 \mathrm{~Hz}, 2 \mathrm{H}), 6.22(\mathrm{t}, J=8 \mathrm{~Hz}, 4 \mathrm{H}), 6.78(\mathrm{~d}, J=9 \mathrm{~Hz}$, $2 \mathrm{H}), 6.87$ (d, $J=9 \mathrm{~Hz}, 2 \mathrm{H}), 6.89$ (s, $2 \mathrm{H}), 7.09$ (m, $4 \mathrm{H}), 7.21(\mathrm{~s}$, $2 \mathrm{H}, 2 \mathrm{CH}=\mathrm{N}), 7.21-7.29(\mathrm{~m}, 4 \mathrm{H}), 7.38(\mathrm{dd}, J=7,8 \mathrm{~Hz}, 2 \mathrm{H})$, $7.57(\mathrm{~d}, J=8.5 \mathrm{~Hz}, 2 \mathrm{H}), 7.88(\mathrm{~d}, J=8 \mathrm{~Hz}, 2 \mathrm{H}), 7.95(\mathrm{~d}, J=$ $8.5 \mathrm{~Hz}, 2 \mathrm{H}), 8.19(\mathrm{~s}, 2 \mathrm{H})$ and $13.00(2 \mathrm{H}, \mathrm{s}, 2 \mathrm{OH}) ; \delta_{\mathrm{C}}\left(\mathrm{CDCl}_{3}\right)$ 24.1, 31.4, 32.5, 33.6, 62.1, 73.3, 119.8, 124.6, 125.7, 126.2, 126.4, $126.5,126.9,127.2,2 \times 127.4,2 \times 128.1,2 \times 128.2,128.3,129.4$, $131.3,2 \times 132.8,2 \times 132.9,133.2,136.1,140.2,141.9,154.5$ and 165.4; $m / z($ FAB $) 965\left(\mathrm{M}+\mathrm{Na}^{+}, 10 \%\right), 943\left(\mathrm{MH}^{+}, 100\right), 511$ (28) and 107 (90) (found: $\mathrm{MH}^{+}$, 943.4500. Calc. for $\mathrm{C}_{66} \mathrm{H}_{59} \mathrm{O}_{4} \mathrm{~N}_{2}$, 943.4475); $v_{\max } / \mathrm{cm}^{-1}$ (KBr) 3359 (broad, O-H), 2927, 2856 and $1631(\mathrm{C}=\mathrm{N})$

Synthesis of unsymmetrical complexes $1 \mathrm{a}$ and $\mathbf{1 b}$. To a solution of $7(348.8 \mathrm{mg}, 0.394 \mathrm{mmol})$ in a mixture of ethanol $(50 \mathrm{ml})$, acetonitrile $(10 \mathrm{ml})$ and dichloromethane $(10 \mathrm{ml})$ was added $\mathrm{Mn}(\mathrm{OAc})_{2} \cdot 4 \mathrm{H}_{2} \mathrm{O}(126.0 \mathrm{mg}, 0.514 \mathrm{mmol})$ and the mixture was stirred in air for $24 \mathrm{~h}$ at room temperature. The solution was concentrated in vacuo to give a dark brown mass $(460 \mathrm{mg})$. The crude product was redissolved in dichloromethane and filtered. The filtrate was concentrated in vacuo to give a dark brown solid, 1a (400 mg, ca. $108 \%$ of the theoretical yield).

Complex 1a (93.6 mg, $0.094 \mathrm{mmol})$ was dissolved in acetonitrile and a solution of $\mathrm{NaPF}_{6}(157.5 \mathrm{mg}, 0.938 \mathrm{mmol})$ in a minimum of water $(1 \mathrm{ml})$ was added. The mixture was stirred for $24 \mathrm{~h}$ at room temperature and then the solvent was removed in vacuo. The crude material was redissolved in dichloromethane and filtered. The filtrate was concentrated in vacuo and purified by column chromatography $\left(\mathrm{SiO}_{2}, \mathrm{CH}_{2} \mathrm{Cl}_{2}-\mathrm{MeOH} 5: 0.5\right)$ to give a dark brown product $\mathbf{1 b}(77.0 \mathrm{mg}, 76 \%$ yield).

Chiral (salen)Mn(III)OAc complex (1a). $\quad m / z$ (FAB) 937 ([M $\mathrm{AcO}^{+}, 100 \%$ ) and 885 (30) (found: $[\mathrm{M}-\mathrm{AcO}]^{+}, 937.3192$. Calc. for $\left.\mathrm{C}_{63} \mathrm{H}_{50} \mathrm{~N}_{2} \mathrm{O}_{3} \mathrm{Mn}, 937.3202\right) ; \mathrm{m} / z\left(\mathrm{ES}^{-}\right) 59\left(\mathrm{CH}_{3} \mathrm{CO}_{2}^{-}, 100 \%\right)$; $v_{\max } / \mathrm{cm}^{-1} 1608(\mathrm{C}=\mathrm{N})$.

Chiral (salen)Mn(III)PF $\mathbf{P F}_{6}$ complex (1b). $\mathrm{m} / \mathrm{z}$ (FAB) 938 $\left(\left[\mathrm{MH}-\mathrm{PF}_{6}\right]^{+}, 85 \%\right), 937\left(\left[\mathrm{M}-\mathrm{PF}_{6}\right]^{+}, 100\right), 885$ (20), 215 
(60), 135 (73) and 107 (77) (found: $\left[\mathrm{M}-\mathrm{PF}_{6}\right]^{+}, 937.3180$. Calc. for $\left.\mathrm{C}_{63} \mathrm{H}_{50} \mathrm{~N}_{2} \mathrm{O}_{3} \mathrm{Mn}, 937.3202\right) ; \mathrm{m} / z\left(\mathrm{ES}^{-}\right) 145\left(\mathrm{PF}_{6}{ }^{-}, 100 \%\right)$; $v_{\max } / \mathrm{cm}^{-1} 1608(\mathrm{C}=\mathrm{N})$.

Chiral (salen)Mn(III)PF $\mathbf{P F}_{6}$ complex (2). The procedure was similar to that for complex $\mathbf{1 b}$. The crude product was purified by column chromatography $\left(\mathrm{SiO}_{2}, \mathrm{CH}_{2} \mathrm{Cl}_{2}-\mathrm{MeOH} 5\right.$ : 0.2) to give dark brown solid 2 (98\% yield).

$m / z(\mathrm{FAB}) 880\left(\left[\mathrm{MH}-\mathrm{PF}_{6}\right]^{+}, 85 \%\right), 879\left(\left[\mathrm{M}-\mathrm{PF}_{6}\right]^{+}, 100\right)$, 827.5 (90), 374 (82) and 149 (57) (found: $\left[\mathrm{M}-\mathrm{PF}_{6}\right]^{+}, 879.2762$. Calc. for $\left.\mathrm{C}_{60} \mathrm{H}_{44} \mathrm{~N}_{2} \mathrm{O}_{2} \mathrm{Mn}, 879.2783\right) ; \mathrm{m} / z\left(\mathrm{ES}^{-}\right) 145\left(\mathrm{PF}_{6}{ }^{-}, 100 \%\right)$; $v_{\max } / \mathrm{cm}^{-1} 1608(\mathrm{C}=\mathrm{N})$.

Mn complex of ligand 19b, chiral (salen)Mn(III)OAc complex. The procedure was similar to that for complex 1a. The crude product was redissolved in dichloromethane and filtered. The solvent was concentrated in vacuo to give the complex (97\% yield) as a dark brown solid.

$m / z(\mathrm{FAB}) 996\left(\left[\mathrm{MH}-\mathrm{CH}_{3} \mathrm{CO}_{2}\right]^{+}, 45 \%\right), 995\left(\left[\mathrm{M}-\mathrm{CH}_{3} \mathrm{CO}_{2}\right]^{+}\right.$, 100), 943 (20), 938 (5), 391 (35), 149 (65) and 107 (50) (found: $\left[\mathrm{MH}-\mathrm{CH}_{3} \mathrm{CO}_{2}\right]^{+}$, 996.3698. Calc. for $\mathrm{C}_{66} \mathrm{H}_{57} \mathrm{~N}_{2} \mathrm{O}_{4} \mathrm{Mn}$, 996.3699); $\mathrm{m} / z\left(\mathrm{ES}^{-}\right) 59\left(\mathrm{CH}_{3} \mathrm{CO}_{2}^{-}, 100 \%\right) ; v_{\max } / \mathrm{cm}^{-1} 1608(\mathrm{C}=\mathrm{N})$.

Synthesis of $N-\left[(R)-\left(2-h y d r o x y-2 '-p h e n y l-1,1^{\prime}\right.\right.$-binaphthyl-3ylmethylene) $]-N^{\prime}-[(R)-2-h y d r o x y-6-(3-b e n z o y l o x y p r o p y l)-2 '-p h e n y l-$ 1,1'-binaphthyl-3-ylmethylene]-1S,2S-cyclohexanediamine (20). To a solution of ligand $7(40.1 \mathrm{mg}, 0.0453 \mathrm{mmol})$ in dry dichloromethane $(5 \mathrm{ml})$ at $0{ }^{\circ} \mathrm{C}$ under argon was added triethylamine $(3.0 \mathrm{ml}$ of $0.023 \mathrm{M}$ solution in dry dichloromethane, $0.069 \mathrm{mmol})$ under argon. A solution of benzoyl chloride $(0.80 \mathrm{ml}$ of $0.067 \mathrm{M}$ solution in dry dichloromethane, $0.054 \mathrm{mmol}$ ) was slowly added and the mixture was stirred at $0{ }^{\circ} \mathrm{C}$ for $24 \mathrm{~h}$. The reaction was monitored by $\mathrm{TLC}\left(\mathrm{SiO}_{2}\right.$, hexane-ether $3: 5 ; 7 R_{\mathrm{f}}=$ 0.4 ), but showed no reaction. Therefore, the mixture was warmed to room temperature for an additional $24 \mathrm{~h}$, at which time TLC indicated the presence of one new component at $R_{\mathrm{f}}=0.6$ and a spot at $R_{\mathrm{f}}=0.2$, which was nevertheless presumed to be the starting material, 7. An aliquot of the solution ( $c a .2 \mathrm{ml}$ ) was diluted to $c a .10 \mathrm{ml}$ with dichloromethane, washed with saturated aqueous $\mathrm{NaHCO}_{3}(10 \mathrm{ml})$ and brine $(10 \mathrm{ml})$, and then dried over anhydrous $\mathrm{MgSO}_{4}$. Evaporation of the solvent gave a cream solid product, $10 \mathrm{mg}$. Purification by column chromatography $\left(\mathrm{SiO}_{2}\right.$, hexane-ether $3: 5)$ gave $7(5.9 \mathrm{mg})$ and $\mathbf{2 0}(3.2 \mathrm{mg})$.

The rest of the reaction mixture was heated to reflux for an additional $24 \mathrm{~h}$. The organic phase was then washed with saturated aqueous $\mathrm{NaHCO}_{3}(10 \mathrm{ml})$ and brine $(10 \mathrm{ml})$, and then dried over anhydrous $\mathrm{MgSO}_{4}$. Evaporation of the solvent gave a cream solid product, $30 \mathrm{mg}$. Purification by column chromatography gave 7 (4.4 $\mathrm{mg})$ and 20 (12.6 mg).

$\delta_{\mathrm{H}}\left(\mathrm{CDCl}_{3}\right)$ 1.35-2.00 (m, $\left.12 \mathrm{H}\right), 3.15(\mathrm{~m}, 2 \mathrm{H}), 4.15(\mathrm{~m}, 2 \mathrm{H})$, $6.09(\mathrm{t}, J=7 \mathrm{~Hz}, 1 \mathrm{H}), 6.14(\mathrm{t}, J=7 \mathrm{~Hz}, 1 \mathrm{H}), 6.25(\mathrm{t}, J=$ $8 \mathrm{~Hz}, 2 \mathrm{H}), 6.36(\mathrm{t}, J=8 \mathrm{~Hz}, 2 \mathrm{H}), 6.77(\mathrm{bs}, 1 \mathrm{H}), 6.82(\mathrm{~d}, J=$ $9 \mathrm{~Hz}, 1 \mathrm{H}), 6.85(\mathrm{~d}, J=9 \mathrm{~Hz}, 1 \mathrm{H}), 6.90(\mathrm{~m}, 2 \mathrm{H}), 6.99-7.09$ (m, $6 \mathrm{H}), 7.13(\mathrm{~m}, 2 \mathrm{H}), 7.20-7.30(\mathrm{~m}, 4 \mathrm{H}), 7.33-7.43(\mathrm{~m}, 4 \mathrm{H})$, $7.48(\mathrm{~m}, 1 \mathrm{H}), 7.56(\mathrm{~d}, J=8 \mathrm{~Hz}, 1 \mathrm{H}), 7.57(\mathrm{~d}, J=8 \mathrm{~Hz}, 1 \mathrm{H})$, $7.88(\mathrm{~d}, J=8 \mathrm{~Hz}, 2 \mathrm{H}), 7.95(\mathrm{~d}, J=8 \mathrm{~Hz}, 4 \mathrm{H}), 8.10(\mathrm{~s}, 1 \mathrm{H})$, $8.12(\mathrm{~s}, 1 \mathrm{H}), 12.97(\mathrm{bs}, 1 \mathrm{H}, \mathrm{OH})$ and $13.06(\mathrm{bs}, 1 \mathrm{H}, \mathrm{OH}) ; \mathrm{m} / \mathrm{z}$ (FAB) $989\left(\mathrm{MH}^{+}, 53 \%\right), 988\left(\mathrm{M}^{+}, 57\right)$ and 827 (7) (found: $\mathrm{MH}^{+}$, 989.4303. Calc. for $\left.\mathrm{C}_{70} \mathrm{H}_{57} \mathrm{~N}_{2} \mathrm{O}_{4}, 989.4318\right) ; v_{\max } / \mathrm{cm}^{-1}$ (thin film) $1718(\mathrm{C}=\mathrm{O})$ and $1632(\mathrm{C}=\mathrm{N})$.
Synthesis of $\left\{N-\left[(R)-\left(2-h y d r o x y-2^{\prime}\right.\right.\right.$-phenyl-1,1'-binaphthyl-3ylmethylene) $]-N^{\prime}-[(R)-2$-hydroxy-6-(3-benzoyloxypropyl)-2'-phenyl1,1' - binaphthyl - 3 - ylmethylene] - $1 S, 2 S$ - cyclohexanediamine Mn(III) trifluoromethanesulfonate (21). To a solution of 1c (46.6 mg, $0.0429 \mathrm{mmol}$ ) in dry dichloromethane $(5 \mathrm{ml})$ at room temperature was added triethylamine $(3.0 \mathrm{ml}$ of a $0.071 \mathrm{M}$ solution in dry dichloromethane, $0.21 \mathrm{mmol}$ ) under argon. A solution of benzoyl chloride $(3.0 \mathrm{ml}$ of a $0.069 \mathrm{M}$ solution in dichloromethane, $0.21 \mathrm{mmol}$ ) was slowly added and the mixture was refluxed for $48 \mathrm{~h}$. The mixture was quenched with saturated aqueous $\mathrm{NaHCO}_{3}(10 \mathrm{ml})$, separated, and the organic layer was washed with brine $(10 \mathrm{ml})$, dried over anhydrous $\mathrm{MgSO}_{4}$ and concentrated in vacuo to give a dark brown solid, $53.1 \mathrm{mg}$. Purification by column chromatography $\left(\mathrm{SiO}_{2}, \mathrm{DCM}-\mathrm{MeOH} 5\right.$ : 0.6) gave 21 (36.8 mg, 72\% yield) and 1c (2.2 mg, 5\%).

$\mathrm{m} / \mathrm{z}(\mathrm{FAB}) 1041\left(\left[\mathrm{M}-\mathrm{F}_{3} \mathrm{CSO}_{3}\right]^{+}, 20 \%\right)$ and 989 (10) (found: $\left[\mathrm{M}-\mathrm{F}_{3} \mathrm{CSO}_{3}\right]^{+}$, 1041.3450. Calc. for $\left.\mathrm{C}_{70} \mathrm{H}_{54} \mathrm{~N}_{2} \mathrm{O}_{4} \mathrm{Mn}, 1041.3464\right)$; $\mathrm{m} / \mathrm{z}\left(\mathrm{ES}^{-}\right) 149\left(\mathrm{~F}_{3} \mathrm{CSO}_{3}^{-}, 100 \%\right) ; v_{\max } / \mathrm{cm}^{-1}(\mathrm{KBr}) 1715(\mathrm{C}=\mathrm{O})$ and $1610(\mathrm{C}=\mathrm{N})$.

Attachment of the unsymmetrical complex 1a to polystyrenecarbonyl chloride. Complex 1a $(0.156 \mathrm{~g}, 0.157 \mathrm{mmol})$ in dichloromethane $(5 \mathrm{ml})$ was treated with excess triethylamine $(0.12 \mathrm{M}$ solution in dry dichloromethane, $5.0 \mathrm{ml}, 0.60 \mathrm{mmol})$ and the mixture was added to polystyrenecarbonyl chloride $(0.125 \mathrm{~g}$, $\left.1.17 \mathrm{mmol} \mathrm{g}{ }^{-1}, 0.146 \mathrm{mmol}\right)$, swollen in dichloromethane $(5 \mathrm{ml})$ for $1 \mathrm{~h}$ and the mixture was heated at reflux for $6 \mathrm{~d}$. The resulting polymer was filtered, washed with $\mathrm{CH}_{2} \mathrm{Cl}_{2}(20 \mathrm{ml}), \mathrm{H}_{2} \mathrm{O}(20 \mathrm{ml})$, THF (20 ml), THF- $\mathrm{H}_{2} \mathrm{O}$ (1 : 1, $\left.20 \mathrm{ml}\right), \mathrm{H}_{2} \mathrm{O}$ (20 ml), $\mathrm{CH}_{2} \mathrm{Cl}_{2}(20$ $\mathrm{ml})$, and finally $\mathrm{MeOH}(20 \mathrm{ml})$. After being dried in a vacuum oven for $24 \mathrm{~h}$, the resin (polymer A, 25a, $0.0981 \mathrm{~g}$ ) was obtained as a pale brown solid. AAS suggested that the polymer contained around $0.096 \mathrm{mmol} \mathrm{g}^{-1} \mathrm{Mn}$.

$v_{\max } / \mathrm{cm}^{-1}(\mathrm{KBr}) 1721(\mathrm{C}=\mathrm{O})$ and $1602(\mathrm{C}=\mathrm{N})$.

Attachment of the unsymmetrical complex 1c to polystyrenecarbonyl chloride and subsequent ion-exchange. The procedure for the attachment of complex 1c was similar to that for 1a except that reflux was maintained for $2 \mathrm{~d}$. After being dried in a vacuum oven for $24 \mathrm{~h}$, polymer 25c was obtained as a dark brown powder. AAS suggested that it contained around $0.12 \mathrm{mmol} \mathrm{g}^{-1} \mathrm{Mn}$.

The resin 25c $(0.103 \mathrm{~g})$ was swollen in a mixture of dioxane $(5 \mathrm{ml})$, ethanol $(5 \mathrm{ml})$ and acetonitrile $(5 \mathrm{ml})$ for $1 \mathrm{~h}$, a solution of $\mathrm{NaPF}_{6}(25.0 \mathrm{mg}, 0.149 \mathrm{mmol})$ in a minimum of water $(1 \mathrm{ml})$ was added and the mixture was stirred for $24 \mathrm{~h}$ at room temperature. The polymer was filtered off, washed with EtOH $(20 \mathrm{ml}), \mathrm{H}_{2} \mathrm{O}$ (20 ml), $\mathrm{CH}_{2} \mathrm{Cl}_{2}(20 \mathrm{ml}), \mathrm{H}_{2} \mathrm{O}(20 \mathrm{ml}), \mathrm{CH}_{2} \mathrm{Cl}_{2}(20 \mathrm{ml})$ and finally $\mathrm{MeOH}(20 \mathrm{ml})$. After being dried in a vacuum oven $\left(50{ }^{\circ} \mathrm{C}\right.$, $10 \mathrm{mmHg})$ for $24 \mathrm{~h}$, polymer $\mathbf{B}(\mathbf{2 5 b}, 0.0922 \mathrm{~g})$ was obtained as a dark brown solid.

Attachment of the unsymmetrical complex $1 \mathrm{~b}$ to polystyrenecarbonyl chloride. The procedure for the attachment of complex $\mathbf{1 b}$ was similar to that for 1a except that reflux was maintained for 2 d. Polymer C (25b) was obtained as a dark brown solid. AAS suggested that the polymer contained around $0.24 \mathrm{mmol} \mathrm{g}^{-1} \mathrm{Mn}$. 
General procedure for the epoxidation of 1,2-dihydronaphthalene (26) using free or polymer-supported unsymmetrical chiral (salen)Mn complexes

The procedure for the free complexes was as follows. To a solution of 1,2-dihydronaphthalene (26; $0.2 \mathrm{mmol})$, 4-PPNO $(0.05 \mathrm{mmol})$ and hexadecane $(0.2 \mathrm{mmol})$ as an internal standard in dichloromethane $(2.5 \mathrm{ml})$ was added catalyst $\mathbf{1 b}$ or $\mathbf{2}(0.02 \mathrm{mmol})$ and the mixture was cooled to $0{ }^{\circ} \mathrm{C}$. A solution of $\mathrm{NaOCl}$ in phosphate buffer $(1.0 \mathrm{ml}, 0.588 \mathrm{M}, 0.6 \mathrm{mmol})(\mathrm{pH}=11.4)$ was added. The two-phase system was stirred at $0{ }^{\circ} \mathrm{C}$. The progress of the reaction was monitored by $\mathrm{GC}$ and the results are recorded in Table 1. After the reaction was completed, the layers were separated, the organic layer was washed with water $(2 \times 10 \mathrm{ml})$ and the aqueous layer was extracted with dichloromethane $(2 \times$ $10 \mathrm{ml})$. The organic extracts were combined with the original organic layer, dried over $\mathrm{Na}_{2} \mathrm{SO}_{4}$ and concentrated in vacuo. Purification by column chromatography $\left(\mathrm{SiO}_{2}\right.$, pet. $40-60{ }^{\circ} \mathrm{C}-$ ethyl acetate, $5: 0-5: 0.2)$ gave epoxide 27 as a cream oil.

$\delta_{\mathrm{H}}\left(\mathrm{CDCl}_{3}\right) 1.65(\mathrm{~m}, 1 \mathrm{H}), 2.30(\mathrm{~m}, 1 \mathrm{H}), 2.44(\mathrm{~m}, 1 \mathrm{H}), 2.68(\mathrm{~m}$, $1 \mathrm{H}), 3.62(\mathrm{~m}, 1 \mathrm{H}), 3.74(\mathrm{~d}, J=4 \mathrm{~Hz}, 1 \mathrm{H}), 6.98(\mathrm{~d}, J=7 \mathrm{~Hz}$, $1 \mathrm{H}), 7.08-7.17(\mathrm{~m}, 2 \mathrm{H})$ and $7.28(\mathrm{~d}, J=8 \mathrm{~Hz}, 1 \mathrm{H}) ; \delta_{\mathrm{C}}\left(\mathrm{CDCl}_{3}\right)$ 21.8, 24.4, 52.7, 55.1, 126.1, $2 \times 128.4,129.5,132.6$ and 136.7.

The enantiomeric excess (ee) was determined by ${ }^{1} \mathrm{H}$ NMR spectroscopy using the chiral shift reagent tris[3(heptafluoropropylhydroxymethylene)-(+)-camphorate]

$\left(\mathrm{Eu}(\mathrm{hfc})_{3}\right)$ in $\mathrm{CDCl}_{3}$.

The procedure for use of the polymer-bound complexes was as follows. Polymer A, B or C (as indicated in Table 1) was swelled in dichloromethane $(2 \mathrm{ml})$ for $1 \mathrm{~h}$. A solution containing 1,2dihydronaphthalene ( 1 eq.), 4-PPNO (0.25 eq.) and hexadecane as an internal standard in dichloromethane $(2 \mathrm{ml})$ was added and the mixture was cooled to $0{ }^{\circ} \mathrm{C}$. A solution of $\mathrm{NaOCl}$ in phosphate buffer ( $0.588 \mathrm{M}, 5$ eq., $\mathrm{pH}=11.4)$ was added, the mixture was stirred at $0{ }^{\circ} \mathrm{C}$ and the progress of the reaction was monitored by GC. After the appropriate time the suspension was filtered and the residue was washed with $\mathrm{CH}_{2} \mathrm{Cl}_{2}(50 \mathrm{ml}), \mathrm{H}_{2} \mathrm{O}(50 \mathrm{ml}), \mathrm{CH}_{2} \mathrm{Cl}_{2}$ $(50 \mathrm{ml})$, and finally $\mathrm{MeOH}(50 \mathrm{ml})$. After being dried in a vacuum oven $\left(50{ }^{\circ} \mathrm{C}, 10 \mathrm{mmHg}\right)$ for $24 \mathrm{~h}$ the polymer was available for reuse. This procedure was repeated after each use of the polymer. The filtrate was collected and concentrated in vacuo. The residue was then treated in an identical manner to the product obtained from the reactions involving free complexes.

\section{Acknowledgements}

We thank the University of Wales Swansea for financial support and the EPSRC Mass Spectrometry Centre at Swansea for the mass spectra. We also thank the EPSRC, the Higher Education Funding Council for Wales (ELWa-HEFCW) and the University of Wales Swansea for grants that enabled the purchase and upgrading of NMR equipment used in the course of this work. G. A. El-Hiti thanks the Royal Society of Chemistry for an international author grant.

\section{References}

1 (a) E. M. Jacobsen, in Catalytic Asymmetric Synthesis, ed. I. Oijima, VCH, New York, 1993, ch. 4.2, p. 159; (b) E. N. Jacobsen and M. H.
$\mathrm{Wu}$, in Comprehensive Asymmetric Catalysis II, ed. E. N. Jacobsen, A. Pfaltz and H. Yamamoto, Springer-Verlag, New York, 1999, ch. 18.2 , p. 649 .

2 (a) T. Katsuki, J. Mol. Catal. A: Chem., 1996, 113, 87; (b) T. Katsuki, Coord. Chem. Rev., 1995, 140, 189; (c) Y. N. Ito and T. Katsuki, Bull. Chem. Soc. Jpn., 1999, 72, 603; (d) T. Katsuki, in Catalytic Asymmetric Synthesis, ed. I. Oijima, VCH, New York, 2000, ch. 6.6B, p. 287.

3 B. Pugin and H.-U. Blaser, in Comprehensive Asymmetric Catalysis III, ed. E. N. Jacobsen, A. Pfaltz and H. Yamamoto, Springer-Verlag, New York, 1999, ch. 38.1, p. 1367.

4 (a) D. C. Sherrington, Catal. Today, 2000, 57, 87; (b) B. Clapham, T. S. Reger and K. D. Janda, Tetrahedron, 2001, 57, 4637 (see Section 2.4); (c) D. C. Sherrington, Chem. Commun., 1998, 2275.

5 (a) B. B. De, B. B. Lohray and P. K. Dhal, Tetrahedron Lett., 1993, 34, 2371; (b) B. B. De, B. B. Lohray, S. Sivaram and P. K. Dhal, Macromolecules, 1994, 27, 1291; (c) B. B. De, B. B. Lohray, S. Sivaram and P. K. Dhal, Tetrahedron: Asymmetry, 1995, 6, 2105; (d) B. B. De, B. B. Lohray, S. Sivaram and P. K. Dhal, J. Polym. Sci., Polym. Chem. Ed., 1997, 35, 1809; (e) F. Minutolo, D. Pini, A. Petri and P. Salvadori, Tetrahedron: Asymmetry, 1996, 7, 2293; (f) F. Minutolo, D. Pini and P. Salvadori, Tetrahedron Lett., 1996, 37, 3375.

6 T. S. Reger and K. D. Janda, J. Am. Chem. Soc., 2000, 122, 6929; for the preparation of the resins, see: P. H. Toy and K. D. Janda, Tetrahedron Lett., 1999, 40, 6329.

7 R. I. Kureshy, N. H. Khan, S. H. R. Abdi and P. Iyer, React. Funct. Polym., 1997, 34, 153.

8 (a) L. Canali and D. C. Sherrington, Chem. Soc. Rev., 1999, 28, 85; (b) L. Canali, E. Cowan, H. Deleuze, C. L. Gibson and D. C. Sherrington, Chem. Commun., 1998, 2561; (c) L. Canali, D. C. Sherrington and H. Deleuze, React. Funct. Polym., 1999, 40, 155; (d) L. Canali, E. Cowan, H. Deleuze, C. L. Gibson and D. C. Sherrington, J. Chem. Soc., Perkin Trans. 1, 2000, 2055.

9 C. E. Song, E. J. Roh, B. M. Yu, D. Y. Chi, S. C. Kim and K.-J. Lee, Chem. Commun., 2000, 615.

10 (a) I. F. J. Vankelecom, D. Tas, R. F. Parton, V. Van de Vyver and P. A. Jacobs, Angew. Chem., Int. Ed. Engl., 1996, 35, 1346; (b) I. F. J. Vankelecom, K. A. L. Vercruysse, P. E. Neys, D. W. A. Tas, B. M. Janssen, P.-P. Knops-Gerrits and P. A. Jacobs, Top. Catal., 1998, 5, 125; (c) K. B. M. Janssen, I. Laquiere, W. Dehaen, R. F. Parton, I. F. J. Vankelecom and P. A. Jacobs, Tetrahedron: Asymmetry, 1997, 8, 3481

11 M. J. Sabater, A. Corma, A. Domenech, V. Fornés and H. García, Chem. Commun., 1997, 1285.

12 S. B. Ogunwumi and T. Bein, Chem. Commun., 1997, 901.

13 J. M. Fraile, J. I. García, J. Massam and J. A. Mayoral, J. Mol. Catal. A: Chem., 1998, 136, 47.

14 D. Pini, A. Mandoli, S. Orlandi and P. Salvadori, Tetrahedron: Asymmetry, 1999, 10, 3883.

15 (a) L. Frunza, H. Kosslick, H. Landmesser, E. Höft and R. Fricke, J. Mol. Catal. A: Chem., 1997, 123, 179; (b) G.-J. Kim and S.-H. Kim, Catal. Lett., 1999, 139.

16 (a) G.-J. Kim and J.-H. Shin, Tetrahedron Lett., 1999, 40, 6827; (b) P. Piaggio, C. Langham, P. McMorn, D. Bethell, P. C. Bulman-Page, F. E. Hancock, C. Sly and G. J. Hutchings, J. Chem. Soc., Perkin Trans. 2, $2000,143$.

17 (a) F. Bigi, L. Moroni, R. Maggi and G. Sartori, Chem. Commun., 2002, 716; (b) S. Xiang, Y. Zhang, Q. Xin and C. Li, Chem. Commun., 2002, 2696; (c) H. Zhang, S. Xiang and C. Li, Chem. Commun., 2005, 1209.

18 A. R. Silva, J. Vital, J. L. Figueiredo, C. Freire and B. de Castro, New J. Chem., 2003, 1511.

19 K. Smith and C.-H. Liu, Chem. Commun., 2002, 886.

20 J. Skarzewski, A. Gupta and A. Vogt, J. Mol. Catal. A: Chem., 1995, 103, L63.

21 H. Ssaki, R. Irie, T. Hamada, K. Suzuki and T. Katsuki, Tetrahedron, 1994, 50, 11827.

22 A. Spencer, J. Organomet. Chem., 1983, 258, 101.

23 A. Zarecki and J. Wicha, Synthesis, 1996, 455.

24 W. E. Bachmann and A. S. Dreiding, J. Am. Chem. Soc., 1949, 71, 3222.

25 (a) J. Lopez, S. Liang and X. R. Bu, Tetrahedron Lett., 1998, 39, 4199; (b) J. Lopez, E. A. Mintz, F.-L. Hsu and X. R. Bu, Tetrahedron: Asymmetry, 1998, 9, 3741. 
26 A. M. Daly, C. T. Dalton, M. F. Renehan and D. G. Gilheany, Tetrahedron Lett., 1999, 40, 3617.

27 E. J. Campbell and S. T. Nguyen, Tetrahedron Lett., 2001, 42, 1221.

28 (a) X. Beebe, N. E. Schore and M. J. Kurth, J. Org. Chem., 1995, 60, 4196; (b) J. M. Frechet and C. Schuerch, J. Am. Chem. Soc., 1971, 93, 492.
29 X. Beebe, N. E. Schore and M. J. Kurth, J. Am. Chem. Soc., 1992, 114, 10061.

30 T. M. Fyles and C. C. Leznoff, Can. J. Chem., 1976, 54, 935.

31 (a) C. C. Leznoff and D. M. Dixit, Can. J. Chem., 1977, 55, 3351; (b) T. M. Fyles and C. C. Leznoff, Can. J. Chem., 1978, 56, 1031.

32 T. Kuroki, T. Hamada and T. Katsuki, Chem. Lett., 1995, 339.

33 Y. N. Ito and T. Katsuki, Tetrahedron Lett., 1998, 39, 4325. 